\title{
Michał Rosenberg
}

Oddziałowe Archiwum Instytutu Pamięci Narodowej w Warszawie

\section{Działalność sekcji branżowych NSZZ "Solidarność" w latach 1980-1981 na przykładzie Krajowej Komisji Porozumiewawczej NSZZ „Solidarność" Pracowników Teatru}

Zarys treści: Artykuł ukazuje proces formowania się i działalność Krajowej Komisji Porozumiewawczej NSZZ Solidarność Pracowników Teatru. Jej dzieje zostały przedstawione na tle historii związków zawodowych w teatrze polskim. Ważnym epizodem w historii sekcji jest jej konflikt $\mathrm{z}$ władzami SPATiF oraz powstały w jego wyniku rozłam.

Słowa kluczowe: Polska, polityka, kultura, teatr, „Solidarność”, związki zawodowe Keywords: Poland, policy, culture, theatre, "Solidarity", trade unions

Struktura branżowa NSZZ „Solidarność” cieszyła się do tej pory dużo mniejszym zainteresowaniem badaczy niż jej struktura terenowa. Nadal nie znamy w stopniu większym niż ogólny relacji pomiędzy nimi czy też pomiędzy poszczególnymi sekcjami branżowymi. Tylko nieliczne doczekały się odrębnych opracowań ${ }^{1}$. Do zbadania pozostają również stosunki pomiędzy sekcjami a władzami związku i powołanymi przez nie agendami, które miały działać w tym środowisku². Wciąż otwarte są pytania, czy i w jakim stopniu Krajowa Komisja Porozumiewawcza

\footnotetext{
${ }^{1}$ Zob. np. T. Bochwic, Narodziny i działalność Solidarności Oświaty i Wychowania 1980-1989, Warszawa 2000; N. Jarska, Niezależny ruch oświatowy i nauka niezależna 1980-1989, w: NSZZ „Solidarność" 1980-1989, t. 2, red. Ł. Kamiński, G. Waligóra, Warszawa 2010, s. 147-187; T. Kozłowski, J. Olaszek, Niezależny ruch chłopski w Polsce 1980-1989, w: ibidem, s. 75-136; J. Schabieński, K. Sychowicz, Marzenia o orle w koronie. Nauczyciele i młodzież Polski pótnocno-wschodniej wobec władzy w latach 1980-1986, Białystok 2004, s. 9-20.

2 W grudniu 1980 r. KKP powołała zespół mający zajmować się sekcjami branżowymi. W maju 1981 r. zastąpił go Zespół Roboczy ds. Sekcji Branżowych i Zakładowych; Krajowa Komisja Porozumiewawcza, Komisja Krajowa NSZZ „Solidarnośc”, w: Encyklopedia „Solidarności”, t. 1, Warszawa 2010, s. 219-221.
} 
(KKP), a później Komisja Krajowa (KK) NSZZ „Solidarność” ingerowały $\mathrm{w}$ wewnętrzne konflikty $\mathrm{w}$ sekcjach oraz $\mathrm{w}$ jaki sposób wspierały sekcje $\mathrm{w}$ sporach $\mathrm{z}$ władzami.

Niniejszy artykuł jest niewielkim przyczynkiem do opisania historii ruchu branżowego NSZZ „Solidarność”. Przede wszystkim starałem się w nim odtworzyć główne postulaty teatralnej „Solidarności”, a także działania podejmowane $\mathrm{w}$ celu ich realizacji. Zależało mi również na prześledzeniu, czy ograniczały się one jedynie do sfery socjalno-bytowej, czy też, być może, miały również charakter propozycji programowych. Próbowałem również przyjrzeć się sposobowi postępowania sekcji teatralnej wobec innych organizacji działających w środowisku teatralnym oraz organów administracji państwowej.

\section{Związki zawodowe w teatrze polskim do 1980 roku}

Historia ruchu związkowego w polskim teatrze sięga roku 1919. Wraz z odrodzeniem się państwa powstał Związek Zawodowy Artystów Scen Polskich (ZASP), który przez dwadzieścia lat bronił interesów, jak wówczas określano, aktorstwa polskiego. W czasie okupacji ZASP działał w warunkach konspiracyjnych, skupiając się przede wszystkim na organizowaniu materialnej pomocy dla środowiska teatralnego ${ }^{3}$. Do jawnej działalności powrócił w grudniu 1944 r. i funkcjonował do roku 1949, kiedy to pod wpływem nasilającej się presji władz został zlikwidowany. Uprawnienia związku zawodowego przejął Związek Zawodowy Pracowników Sztuki i Kultury (w latach 1957-1961 funkcjonował pod nazwą Związek Zawodowy Pracowników Instytucji Artystycznych, a następnie jako Związek Zawodowy Pracowników Kultury i Sztuki - ZZPKiS) ${ }^{4}$, działający w ramach Komisji Centralnych Związków Zawodowych, a po 1949 r. - Centralnej Rady Związków Zawodowych (CRZZ). W miejsce ZASP powstało Stowarzyszenie Polskich Artystów Teatru i Filmu (SPATiF) $)^{5}$.

Podczas drugiego zjazdu stowarzyszenia w lutym 1957 r. dokonano zmiany nazwy na SPATiF-ZASP. Za tym symbolicznym gestem i odwołaniem się do historii poszły próby odzyskania uprawnień związkowych, które ostatecznie, po

${ }^{3}$ K.A. Wysiński, Związek Artystów Scen Polskich 1918-1950. Zarys monograficzny, Wrocław 1979, s. 88.

${ }^{4}$ ZZPSiK powstał 14 kwietnia 1949 r. z połączenia pięciu związków zawodowych: Związku Artystów Scen Polskich, Związku Zawodowego Muzyków, Związku Zawodowego Pracowników Radia, Związku Zawodowego Pracowników Filmowych oraz Związku Zawodowego Artystów i Pracowników Teatralnych i Widowiskowych; Mały Słownik Teatru Polskiego (1944-1964), „Pamiętnik Teatralny" 1965, nr 3-4, s. 275.

${ }^{5}$ K.A. Wysiński, Związek Artystów Scen Polskich 1918-1950..., s. 96-106, 128-129; E. Krasiński, Związek Zawodowy Artystów Scen Polskich 1944-1949, „Pamiętnik Teatralny” 2008, nr 3-4, s. 186-216; Mały Słownik Teatru Polskiego..., s. 254, 276. 
ponad dwóch latach starań, zakończyły się niepowodzeniem6 ${ }^{6}$ Relacje ze ZZPKiS układały się zazwyczaj źle. SPATiF oskarżało związek o małą aktywność w walce o prawa ludzi teatru i nazbyt rozrośniętą strukturę administracyjną, ZZPKiS co jakiś czas wytykał stowarzyszeniu zapędy do przejmowania jego kompetencji. Wyraźna zmiana na tym polu nastąpiła w połowie lat 60. i trwała przez dekadę lat 70., kiedy na czele związku stali dwaj aktorzy, a jednocześnie członkowie SPATiF: Andrzej Szczepkowski i Mariusz Dmochowski. W tym czasie, za zgodą samego ZZPKiS, a zapewne też i władz zwierzchnich, SPATiF, choć nie posiadał formalnych uprawnień, odgrywał w rzeczywistości rolę związku zawodowego ${ }^{7}$. Przedstawiciele stowarzyszenia brali aktywny udział w pracach nad ważnymi dla środowiska teatralnego regulacjami prawnymi, dotyczącymi sfery socjalno-bytowej, tj. emerytury czy zbiorowe układy pracy. Jak to się w praktyce odbywało, opisał w 1981 r. jego prezes Gustaw Holoubek: „SPATiF [...] w obliczu określonych okoliczności, zajął się sprawami związkowymi i większość ostatnich 20 lat poświęcił albo sporom kompetencyjnym ze Związkiem Zawodowym Pracowników Kultury i Sztuki, albo wyręczaniem go w czynnościach, do których był zobowiązany, a których spełniać nie chciał. Do końca SPATiF nie miał uprawnień formalnych do uprawiania takiej działalności. W związku z tym wszystko, co robił, opierało się na autorytecie środowiska, poszczególnych jego przedstawicieli oraz na dobrej lub złej woli władz. [...] Nie mając wiele do powiedzenia $\mathrm{w}$ zakresie pracy merytorycznej, ukrywając z drugiej strony ze zrozumiałych względów, proceder dochodzenia do kompetencji związku zawodowego - SPATiF informował zaledwie o rezultatach swoich prac, unikając ujawniania, często bardzo żmudnych i interesujących sposobów dochodzenia do owych rezultatów. [...] Styl jaki stosowaliśmy w całym systemie interwencji wobec polityki władz, wobec codziennych incydentów, wynikających z życia teatru. Podstawową wadą tego stylu była prywatność wystąpień, załatwianie po znajomości, liczenie na osobiste wpływy i autorytet, innymi słowy, swoiste łapówkarstwo, tak wówczas praktykowane, tak chętnie widziane przez decydentów"8.

\footnotetext{
${ }^{6}$ K. A. Wysiński, Związek Artystów Scen Polskich 1950-1998. Zarys dziejów, Warszawa 1998, s. 28-33; M. Napiontkowa, Teatr Polskiego Października, Warszawa 2012, s. 192-199.

7 Współpraca ze Związkiem Zawodowym, „Biuletyn Informacyjny SPATiF” 1965, nr 53/54, s. 23-24; Wspótpraca nabiera realnych kształtów, „Biuletyn Informacyjny SPATiF” 1967/1968, nr 83/84, s. 6-10; Realizacja uchwał IX/34 Walnego Zjazdu Delegatów SPATIF-ZASP, „Biuletyn Informacyjny SPATiF” 1971, nr 107, s. 49-52; Przemówienie Prezesa Gustawa Holoubka wygłoszone na uroczystym Plenum Zarządu Głównego z okazji XXX-lecia Teatru Lubelskiego, „Biuletyn Informacyjny SPATiF” 1974, nr 118, s. 5-6.

${ }^{8}$ Instytut Teatralny (dalej: IT), Archiwum Związku Artystów Scen Polskich (dalej: AZASP), sygn. 3/26, Stenogram XIV Nadzwyczajnego Walnego Zjazdu SPATiF-ZASP, 16-17 IV 1981, k. 56-57.
} 


\section{Sytuacja w środowisku teatralnym w drugiej połowie lat siedemdziesiątych}

Od połowy lat 70. narastały w środowisku teatralnym konflikty, które w pełni objawiły się w okresie „Solidarności”. Pierwszy z nich koncentrował się wokół kwestii powołania nowych placówek teatralnych w kilku miastach, które po reformie administracyjnej w 1975 r. uzyskały status miast wojewódzkich. Jeszcze w 1975 r. powstał teatr w Płocku. W ciągu czterech następnych lat utworzono siedem nowych przedsiębiorstw teatralnych, w tym cztery w stolicach nowych województw (Elbląg, Legnica, Słupsk, Radom) $)^{9}$. Było to efektem zarówno ambicji lokalnych decydentów, jak i oczekiwań tamtejszych środowisk kulturalnych ${ }^{10}$. W latach późniejszych owa presja nie malała. Kolejne ośrodki pretendowały do posiadania własnego teatru. Spotykało się to jednak z coraz większym oporem władz centralnych, spowodowanym głównie brakiem środków finansowych na kolejne tego typu inwestycje ${ }^{11}$.

Sytuacja ta wywołała sprzeciw niektórych przedstawicieli władz SPATiF. Już wcześniej pojawiały się opinie, że sieć teatralna w Polsce jest nadmiernie rozbudowana, a brak odpowiednich kadr prowadzi zarówno do obniżenia poziomu sztuki aktorskiej, jak i ogólnego poziomu artystycznego polskiego teatru. Tworzenie nowych placówek miało ten stan dodatkowo pogłębić ${ }^{12}$. Nietrudno się domyślić, że takie stanowisko stało $\mathrm{w}$ sprzeczności $\mathrm{z}$ interesem aktorów oraz innych pracowników teatrów w mniejszych ośrodkach.

Drugą konfliktującą środowisko sprawę przyniósł Protokół dodatkowy z 14 kwietnia 1976 r. do Układu Zbiorowego Pracy dla Pracowników Instytucji Artystycznych z 31 grudnia 1974 r. Ustanawiał on w miejsce umów na czas nieokreślony tylko jedną formę zatrudniania aktorów, którą od tego czasu miały być

${ }^{9}$ W 1979 r. funkcjonowało 65 teatrów dramatycznych. Połowa z nich skupiona była w dużych ośrodkach miejskich (Warszawa, Kraków, Łódź, Wrocław, Poznań, aglomeracja śląska). W samej Warszawie działało 19 teatrów. Oprócz tego w kraju funkcjonowało 25 teatrów lalkowych; Instytut Teatralny (dalej: IT), Ministerstwo Kultury i Sztuki (dalej: MKiS), Materiały na spotkanie w SPATiF 1980, Informacja dotycząca działalności artystycznej teatrów dramatycznych i lalkowych, bd., bp.

10 Z badań przeprowadzonych wśród 39 działaczy kulturalnych w nowych miastach wojewódzkich wynikało, iż najbardziej pożądaną przez nich instytucją kulturalną był teatr dramatyczny. Na kolejnych miejscach znalazły się gazeta codzienna lub czasopismo społeczno-kulturalne, wojewódzki dom kultury, muzeum, biblioteka wojewódzka, wyższa uczelnia lub filia wyższej uczelni, galeria, kino o wysokim standardzie, orkiestra symfoniczna lub filharmonia, podstawowa lub średnia szkoła muzyczna, sala lub hala widowiskowa, wielofunkcyjny ośrodek kulturalny; A. Wallis, Problemy centralizacji i decentralizacji życia kulturalnego w Polsce w latach 1945-1980, Warszawa 1981, s. 63.

${ }^{11}$ IT MKiS, Departament Teatru 1977, Notatka DTMiE MKiS w sprawie wniosków i postulatów środowiska teatralnego do najwyższych władz partyjnych, bd., bp.

12 Przemówienie Prezesa Gustawa Holoubka..., s. 4. 
umowy na czas określony, rozwiązywane ostatniego dnia każdego sezonu teatralnego, zwane potocznie umowami sezonowymi. Ministerstwo Kultury i Sztuki (MKiS) chciało w ten sposób dać dyrektorom teatrów narzędzie do swobodniejszego kształtowania zespołów artystycznych, co z kolei miało przeciwdziałać tendencjom prowadzącym do ich skostnienia. Rozwiązanie to $\mathrm{z}$ jednej strony uzyskało aprobatę władz SPATiF, z drugiej zaś - spotkało się z niezadowoleniem dużej części środowiska aktorskiego. Szczególnie tam, gdzie funkcjonował jeden teatr, który był głównym, a w wielu wypadkach jedynym źródłem utrzymania. Aktorzy z mniejszych ośrodków, nieznani szerszej publiczności, rzadko mogli liczyć na dodatkowe dochody za udział w audycjach radiowych, telewizyjnych czy w filmach. Jeśli już się tam pojawiali, to zazwyczaj nie w rolach pierwszoplanowych. Byli oni w dużo większym stopniu zależni od placówki, w której byli zatrudnieni, jej dyrekcji, lokalnych decydentów, niż aktorzy z większych ośrodków. Utrata pracy stawiała ich w dużo gorszym położeniu niż ich kolegów z Warszawy, Łodzi czy Krakowa ${ }^{13}$.

Jak widać, obie przedstawione powyżej sprawy zarysowują konflikt na linii mniejsze ośrodki kontra władze SPATiF, które, jak wcześniej wspomniano, pełniło w rzeczywistości funkcję związku zawodowego. Część środowiska teatralnego, zatrudniona w placówkach w mniejszych miejscowościach, mogła odbierać poczynania Zarządu Głównego stowarzyszenia jako sprzeczne z jej interesem. Władze SPATiF coraz częściej postrzegane były nie jako reprezentant całego środowiska, ale przede wszystkim aktorów pracujących w dużych ośrodkach teatralnych. Choć na razie nie można mówić o otwartym konflikcie, a jedynie o braku wzajemnego zaufania.

\section{Kultura w programie NSZZ „Solidarność"}

Pierwszym dokumentem o charakterze programowym, w którym pojawily się sprawy kultury były Kierunki działania Związku w obecnej sytuacji kraju. Tezy do dyskusji, opracowane przez Ośrodek Prac Społeczno-Zawodowych przy KKP. W lutym 1981 r. dokument ten omawiany był na jej posiedzeniu. Znalazły się $\mathrm{w}$ nim postulaty dotyczące ujawniania i ograniczania ingerencji cenzorskich oraz wprowadzenia samorządności w działalności stowarzyszeń twórczych ${ }^{14}$. W programie związku, który został uchwalony 7 października 1981 r., ostatniego dnia

${ }^{13}$ Protokół dodatkowy nr 3 z 14 IV 1976 r. do Układu Zbiorowego Pracy dla Pracowników Instytucji Artystycznych z 31 XII 1974 r., s. 1-2, http://www.dialog.gov.pl/uklady-zbiorowe-pracy-zarejestrowane-w-latach-1974-1981/uzp-dla-pracownikow-instytucji-artystycznych-zawarty31-grudnia-1974-r-nr-rejestru-60/ (dostęp: 06 VI 2016).

${ }^{14}$ K. Brzechczyn, Program i myśl polityczna NSZZ „Solidarność, w: NSZZ „Solidarnośćc 1980$-1989 \ldots$, t. 2 , s. 28. 
I Krajowego Zjazdu Delegatów, samorządność środowisk twórczych i naukowych stała się podstawową zasadą organizującą życie społeczno-kulturalne ${ }^{15}$.

Zwracano również uwagę, że uczestnictwo w kulturze wymaga odpowiedniej ilości czasu wolnego, który należy zapewnić każdemu pracownikowi. Służyć temu miało wprowadzenie pięciodniowego tygodnia pracy. Ponadto zauważano, że poprawa sytuacji materialnej społeczeństwa nie może być jedynym celem reform gospodarczych. Powinien nim być również rozwój kulturalny. Zapowiadano także powołanie na wzór Kasy im. Mianowskiego Społecznego Funduszu Kultury Narodowej, a także Społecznej oraz Związkowej Rady Kultury. Ciała te miały zająć się przygotowaniem polityki kulturalnej i rozdzielaniem funduszy ${ }^{16}$.

Uzupełnienie programu stanowiła Deklaracja programowa w sprawie kultury narodowej, która także została przyjęta przez delegatów 7 października. Jej autorem był Jan Józef Lipski. Odwoływano się w niej do dorobku kultury polskiej przy jednoczesnym zaznaczeniu potrzeby otwarcia się na wartości wypracowane przez inne narody europejskie. Docenieniu roli chrześcijaństwa w rozwoju kultury narodowej towarzyszył postulat zachowania neutralności światopoglądowej państwa, ze szczególnym uwzględnieniem sfery edukacji i kultury. Za gwarancję wolności twórczości intelektualnej i sztuki uznano prawo do współegzystowania i ścierania się różnych światopoglądów i kierunków ${ }^{17}$.

Ponadto zapowiadano walkę $\mathrm{z}$ cenzurą i dyskryminacją autorów emigracyjnych. Akcentowano jedność kultury polskiej, bez względu na miejsce, w którym jest tworzona. Podnoszono konieczność demokratyzacji kultury, rozumianej jako udostępnienie jej treści jak najszerszemu gronu obywateli. Nie mogło to jednak stać w sprzeczności z poparciem dla tworzenia dzieł elitarnych. Krytyce poddany został monopol państwa w kulturze, choć to państwo właśnie miało zapewnić jej finansowanie. Dotacje nie mogły jednak stanowić narzędzia do ograniczania samorządności. Samorząd bowiem miał być główną formą funkcjonowania przedsiębiorstw działających w sferze kultury, np. wydawnictw, teatrów, filharmonii czy wytwórni filmowych ${ }^{18}$.

Lektura obu dokumentów skłania do refleksji, że związkowi poza szumnie brzmiącymi frazesami nie udało się przez ponad rok funkcjonowania wypracować spójnego i w miarę szczegółowego programu polityki na poziomie kultury jako całości, a także na poziomie rozwiązań szczegółowych. Kwestią, która w pierwszym rzędzie domagałaby się takiego sprecyzowania, wydaje się być sprawa samorządu. Można odnieść wrażenie, że tego typu rozwiązania, wynikające

15 Ibidem, s. 37.

16 Ibidem.

17 Deklaracja programowa w sprawie kultury narodowej, w: I Krajowy Zjazd Delegatów NSZZ „Solidarność". Stenogramy, t. 2, cz. 2, red. G. Majchrzak, J.M. Owsiński, Warszawa 2013, s. 929-931.

${ }^{18}$ Ibidem. 
z egalitarystycznych tendencji obecnych od samego początku w myśleniu „Solidarności”19, nie do końca sprawdziłyby się w sferze kultury. Nader ważną rolę odgrywa tu bowiem $\mathrm{z}$ trudem poddający się tego rodzaju tendencjom tak nieegalitarny czynnik, jakim jest talent twórców.

\section{Reakcje środowiska teatralnego na powstanie NSZZ "Solidarność"}

27 sierpnia 1980 r. odbyły się pierwsze występy aktorów Teatru Wybrzeże dla strajkujących w Stoczni im. Lenina w Gdańsku i aktorów gdyńskiego Teatru Dramatycznego dla strajkujących w Stoczni im. Komuny Paryskiej w Gdyni. W grupie aktorów z Gdańska znaleźli się Andrzej Blumenfeld, Bogusława Czosnowska, Marian Dworakowski, Elżbieta Goetel, Jerzy Gorzko, Krzysztof Gordon, Jerzy Kiszkis, Jerzy Łapiński, Stanisław Michalski, Andrzej Nowiński, Halina Słojewska, Andrzej Szaciłło, Piotr Suchora, Halina Winiarska oraz z Warszawy Halina Łabonarska. Kierownictwo artystyczne sprawował reżyser, a jednocześnie świeżo mianowany dyrektor Teatru Wybrzeże Maciej Prus. Z kolei wśród występujących w Gdyni znaleźli się Ryszard Fischbach, Stefan Iżyłowski, Tomasz Jankiewicz, Wiesława Kosmalska, Szymon Pawlicki, Grażyna Przybylska. Występy odbyły się również w dniach następnych. W Szczecinie aktorzy Teatru Polskiego dali trzynaście darmowych przedstawień, w tym siedem dla dzieci stoczniowców strajkujących w tym mieście. Przekazali również strajkującym datek w wysokości 7 tys. złotych ${ }^{20}$. Dla uczestników strajku w Nowej Hucie wiersze przez zakładowy radiowęzeł czytała Teresa Budzisz-Krzyżanowska ${ }^{21}$.

Tymczasem kilkoro aktorów teatrów trójmiejskich, którzy brali udział w występach podczas strajków, aktywnie zaangażowało się w działalność związku. Aktor Teatru Dramatycznego w Gdyni Szymon Pawlicki został konsultantem do spraw kultury Prezydium gdańskiego Międzyzakładowego Komitetu Założycielskiego

${ }^{19}$ K. Brzechczyn, op. cit., s. 24.

20 Archiwum Komisji Krajowej NSZZ „Solidarność” (dalej: AKKS), Dokumenty KKP NSZZ „Solidarność” PT (dalej: KKP PT), Protokół z posiedzenia KKP NSZZ „Solidarność” PT, 10 XI 1980, k. 20; materiały teatralnej „Solidarności” zostały opublikowane na stronie internetowej http://www.wszechnica.solidarnosc.org.pl/?page_id=227 (dostęp: $31 \mathrm{~V}$ 2016); L. Biernacki, A. Kazański, NSZZ „Solidarność” Region Gdański, w: NSZZ „Solidarność” 1980-1989. Polska Pótnocna, t. 3, red. Ł. Kamiński, G. Waligóra, Warszawa 2010, s. 27.

${ }^{21}$ E. Elerowska, G. Majkowski, Teatr w Stoczni, „Teatr” 1981, nr 4, s. 19-20; Niekontrolowane natchnienie. Z Maciejem Prusem rozmawia Janusz R. Kowalczyk, „Rzeczpospolita (dodatek specjalny Sierpień 80)" 2005, nr 189, s. 22; Jest mi tu dobrze. Z Teresą Budzisz-Krzyżanowską rozmawia Urszula Biełous, „Polityka” 1989, nr 40, s. 8; K. Braun, Teatr polski 1939-1989. Obszary wolności - obszary zniewolenia, Warszawa 1994, s. 182; P. Sztarbowski, Wspólnota euforii. Rzeczywistość - teatr „Solidarności”, „Didaskalia” 2014, nr 121/122, s. 37-39. 
$(\mathrm{MKZ})^{22}$. Wszedł on również, obok aktorów Teatru Wybrzeże Jerzego Łapińskiego, Haliny Słojewskiej i Haliny Winiarskiej, w skład Komisji Porozumiewawczej Zakładowych Komitetów Założycielskich NSZZ „Solidarność” Instytucji Kulturalnych i Środowisk Twórczych Województwa Gdańskiego, która powstała 28 września. Jej powołanie poprzedziło spotkanie przedstawicieli wszystkich zakładów pracy województwa gdańskiego podległych MKiS z ministrem Zygmuntem Najdowskim. Zgłoszone wówczas postulaty zostały następnie omówione na spotkaniach branżowych w dniach 19-24 września z przedstawicielami ministerstwa pod przewodnictwem wiceministra Józefa Fajkowskiego. Komisja Porozumiewawcza odrzuciła stanowisko ministerstwa jako niezgodne $\mathrm{z}$ duchem porozumień sierpniowych oraz domagała się realizacji i prawidłowej interpretacji tych porozumień, zrównania województwa gdańskiego w nakładach na kulturę przynajmniej do średniej krajowej, zagwarantowania w budżecie co najmniej $2 \%$ nakładów na kulturę, udostępnienia „Solidarności” środków masowego przekazu, zaprzestania represjonowania twórców i działaczy kulturalnych za ich przekonania oraz natychmiastowej zmiany zasad funkcjonowania cenzury ${ }^{23}$.

W pierwszych dniach września, w efekcie chaosu informacyjnego, w wielu zespołach pojawiła się niepewność co do dalszego postępowania. Wątpliwości dotyczyły tego, czy tworzyć nowe związki zawodowe poza strukturą CRZZ, czy ich rolę przejmie SPATiF ${ }^{24}$. Pierwsza koncepcja, która ostatecznie zwyciężyła, była lansowana przez Komitet Założycielski nowych związków zawodowych, utworzony na początku września w Gdańsku przez teatry Wybrzeża. Komitet przystąpił do gdańskiego MKZ i opracował statut nowego związku zawodowego. Miał on podobnie jak ZZPKiS zrzeszać wszystkich pracowników teatru: artystycznych, technicznych i administracyjnych. Nawiązano kontakty z samorzutnie powstającymi w teatrach komitetami założycielskimi niezależnych związków zawodowych i namawiano je do wstępowania do nowego związku²5. W niektórych placówkach, na przykład w Teatrze im. Adama Mickiewicza w Częstochowie, do takich komitetów należeli pracownicy wszystkich pionów teatru ${ }^{26}$.

${ }^{22}$ L. Biernacki, A. Kazański, op. cit., s. 30.

${ }^{23}$ Ibidem, s. 49; AKKS, KKP PT, Pismo do Pełnomocnika Rządu ds. realizacji porozumień sierpniowych, 28 IX 1980, k. 10-11.

${ }^{24}$ Archiwum Oddziału Instytutu Pamięci Narodowej w Katowicach (dalej: AIPN Ka), sygn. 027/385, Meldunki operacyjne Wydziału III KWMO w Częstochowie, 23 IX 1980, 15 X 1980, k. 14-19, M. Zielińska, Protokół pewnego zebrania: „Otworzył się wentyl”. Zapis zebrania aktorskiego [w Teatrze Polskim we Wrocławiu] w dniu 3 września 1980 r., „Didaskalia” 2014, nr 121/122, s. 79-88.

25 AIPN Ka, sygn. 027/385, Odpis listu Komitetu Założycielskiego NZZ w Gdańsku do pracowników Teatru im. A. Mickiewicza w Częstochowie, bd., k. 62; Zob. też P. Zwiernik, NSZZ „Solidarność" w Zielonej Górze, w: NSZZ „Solidarność"1980-1989. Polska Zachodnia, t. 4, red. Ł. Kamiński, G. Waligóra, Warszawa 2010, s. 392.

26 AIPN Ka, sygn. 027/385, Meldunki operacyjne Wydziału III KWMO w Częstochowie, 23 IX 1980, 15 X 1980, k. 14-19. 
Natomiast w innych, jak na przykład w Teatrze Polskim we Wrocławiu, wszystkie działy powołały najpierw własne komitety założycielskie, które następnie stworzyły Komitet Porozumiewawczy, mający reprezentować pracowników wobec dyrekcji teatru ${ }^{27}$.

5 września podczas wystąpienia sejmowego poseł Gustaw Holoubek stwierdził: „Czujemy się w obowiązku, aby w imieniu środowiska, które mam zaszczyt reprezentować, zgłosić pełną solidarność z tym, co wydarzyło się na Wybrzeżu polskim i w reszcie naszego kraju"28. Trzy dni później Zarząd Główny SPATiF przyjął uchwałę, w której „[...] wita z radością i nadzieją głębokie przemiany społeczne i polityczne powstające $\mathrm{w}$ wyniku zwycięskiej walki strajkowej robotników Wybrzeża i całego kraju. Solidaryzujemy się i popieramy powstanie niezależnych związków zawodowych, widząc w ich nieskrępowanym działaniu warunek odrodzenia moralnego, społecznego i politycznego kraju. [...] $\mathrm{Z}$ naszej strony zgłaszamy gotowość koleżeńskiej konsultacji przy tworzeniu form organizacyjnych, statutowych i współpracy w działaniu”29. W podobnym tonie wypowiadał się prezes stowarzyszenia oraz większość mówców podczas nadzwyczajnego zjazdu, który odbył się w 29 września w Teatrze Dramatycznym w Warszawie ${ }^{30}$.

W niektórych miastach przedstawiciele środowiska teatralnego i same teatry odegrały aktywną rolę w procesie tworzenia lokalnych struktur „Solidarności”. Tak było w Zielonej Górze. W tamtejszym Lubuskim Teatrze im. Leona Kruczkowskiego w połowie września odbyło się zebranie przedstawicieli zakładów pracy z miasta i regionu, podczas którego powołano MKZ NSZZ „Solidarność” Ziemia Lubuska. Jego siedzibą w początkowym okresie był budynek teatru, a na jego czele, po rezygnacji pierwotnie wybranego przewodniczącego, stanął asystent kierownika artystycznego Kazimierz Skorupski ${ }^{31}$. Jednak to, że inicjatywa stworzenia MKZ nie wyszła ze środowisk robotniczych, dominacja w jego piętnastoosobowym składzie osób z wyższym wykształceniem oraz fakt, że przewodniczącym został pracownik teatru, stało się źródłem niechęci i braku zaufania załóg zielonogórskich zakładów pracy. Było to również jednym z czynników spowalniających tworzenie się zakładowych komórek związku ${ }^{32}$.

Z kolei inicjatorką powołania komitetu założycielskiego w Teatrze im. Stefana Jaracza w Olsztynie była aktorka Irena Telesz-Burczyk, która następnie została

\footnotetext{
M. Zielińska, op. cit., s. 80.

${ }^{28}$ Cyt. za K.A. Wysiński, Związek Artystów Scen Polskich 1950-1998..., s. 68.

${ }^{29}$ Ibidem, s. 69.

${ }^{30}$ Ibidem, s. 70-72.

${ }^{31}$ O działalności zielonogórskiego MKZ i powodach odwołania Kazimierza Skorupskiego z funkcji jego przewodniczącego w listopadzie 1980 r. zob. A.E. Busse, Taborecik. Solidarność Zielonogórska 1980-1983, Brzezia Łąka 2011, s. 31-128.

32 P. Zwiernik, op. cit., s. 392-394; J. Krakowska, Mikołajska. Teatr i PRL, Warszawa 2011, s. 440.
} 
współzałożycielką i wiceprzewodniczącą olsztyńskiego MKZ oraz członkiem regionalnej Komisji Kultury „Solidarności”33.

\section{Powstanie KKP NSZZ „Solidarność" PT}

10 listopada w sali Teatru Wybrzeże odbyła się konferencja pracowników teatru. W jej trakcie podjęto decyzję o powołaniu Krajowej Komisji Porozumiewawczej NSZZ „Solidarność” Pracowników Teatru (KKP PT) jako jednej z sekcji branżowych związku, który tego samego dnia został ostatecznie zarejestrowany przez Sąd Najwyższy ${ }^{34}$. Dokonano podziału teatralnej Polski na osiem regionó $w^{35}$ i zdecydowano, że siedzibą komisji będzie Gdańsk. Na jej przewodniczącą wybrano Halinę Winiarską ${ }^{36}$. Zebrani podjęli dwanaście uchwał, dotyczących m.in.: poparcia dla strajku pracowników służby zdrowia i oświaty w Urzędzie Wojewódzkim w Gdańsku; zaniechania w $1981 \mathrm{r}$. kosztownych imprez i obchodów teatralnych oraz przeznaczenia zaoszczędzonych w ten sposób środków na inne ważne cele społeczne; wyrażenia najwyższego uznania Halinie Mikołajskiej za jej dotychczasową działalnośćc ${ }^{37}$; zaprzestania represji wobec twórców za ich przekonania i natychmiastowe przywrócenie im prawa wykonywania zawodu; poparcia dla doraźnej komisji powołanej we Wrocławiu, mającej na celu wynegocjowanie dodatku wyrównawczego $\mathrm{w}$ wysokości tysiąca złotych na każdego pracownika zatrudnionego w instytucjach podlegających MKiS i upoważnienia jej do prowadzenia dalszych negocjacji; powołania Komisji do spraw Opracowania Układu Zbiorowego Pracowników Teatru ${ }^{38}$; zreformowania i rozszerzenia sieci szkolnictwa teatral-

33 T. Prusiński, Jest teatr w Olsztynie, Olsztyn 2005, s. 178-179.

34 J. Holzer, „Solidarność” 1980-1981. Geneza i historia, Warszawa 1983, s. 82-87; Z tej okazji odbył się 10 listopada w Teatrze Wielkim w Warszawie koncert Artyści Warszawy „Solidarności”. Koncert wyreżyserował Jerzy Markuszewski, a wystąpili m.in. Halina Mikołajska, Krystyna Janda, Maja Komorowska, Piotr Fronczewski, Daniel Olbrychski, Maciej Rayzacher, Olgierd Łukaszewicz, Damian Damięcki; K. Braun, op. cit., s. 190.

35 Przewodniczącymi regionów zostali wybrani: Małopolska - Jerzy Stuhr, aktor Starego Teatru w Krakowie; Wielkopolska - Teresa Gąsiorowska, aktorka Teatru Lalki i Aktora w Poznaniu; Ziemia Łódzka - Andrzej Herder, aktor Teatru im. Stefana Jaracza w Łodzi; Dolny Śląsk - Zygmunt Bielawski, aktor Teatru Polskiego we Wrocławiu; Mazowsze - Andrzej Zaorski, aktor Teatru Kwadrat w Warszawie; Region Gdański - Halina Winiarska, aktorka Teatru Wybrzeże, Pomorze Zachodnie - Mirosław Gruszczyński, aktor Teatru Polskiego w Szczecinie; Region Śląsko-Dąbrowski - Maria Wilhelm, aktorka Teatru Śląskiego im. Stanisława Wyspiańskiego w Katowicach.

36 AKKS, KKP PT, Sprawozdanie z działalności KKP NSZZ „Solidarność” PT w okresie od 10 listopada 1980 r. do 9 listopada 1981 r., bd., k. 71.

37 Uchwała została odczytana i wręczona adresatce 18 XII 1980 r. podczas uroczystego koncertu w kościele Najświętszego Serca Pana Jezusa w Gdyni, który odbył się na zakończenie obchodów dziesiątej rocznicy Grudnia '70, z udziałem wielu polskich aktorów.

38 Termin i miejsce pierwszego zebrania komisji, w skład której mieli wchodzić przedstawiciele wszystkich regionów, został wyznaczony na 1 XII 1980 r. w Teatrze im. Stefana Jaracza w Łodzi, 
nego, w celu zapewnienia dopływu odpowiedniej ilości zarówno pracowników artystycznych jak i technicznych; poparcia dla apelu stoczniowców o wypowiedzeniu walki alkoholizmowi ${ }^{39}$; niepowoływania na kierownicze funkcje osób, które nie sprawdziły się bądź skompromitowały na zajmowanych wcześniej stanowiskach; poparcia dla studentów PWSFTviT w Łodzi, przeciwstawiających się pomysłowi przeniesienia jej do Warszawy i domagających się zreformowania uczelni ${ }^{40}$.

Jednak uchwałą, która wywołała niemal natychmiastowe następstwa była uchwała dotycząca przeznaczenia na kulturę $2 \%$ dochodu narodowego. Stała się ona głównym postulatem strajku pracowników kultury, którzy 12 listopada przyłączyli się do strajkujących w Urzędzie Wojewódzkim w Gdańsku pracowników służby zdrowia i oświaty. W skład liczącego 11 osób komitetu strajkowego pracowników kultury weszło troje przedstawicieli KKP PT: Halina Słojewska Halina Winiarska oraz Szymon Pawlicki, który został przewodniczącym komitetu. Protest zakończył się 17 listopada podpisaniem porozumienia z komisją rządową, w myśl którego MKiS zobowiązało się przygotować projekt budżetu przewidujący zwiększenie nakładów na kulturę ${ }^{41}$. Tego samego dnia zostało podpisane porozumienie pomiędzy powołaną we Wrocławiu doraźną komisją ds. płacowych, która przyłączyła się do strajku w Urzędzie Wojewódzkim, a Komisją Resortową $\mathrm{MKiS}^{42}$, która zobowiązała się wprowadzić najpóźniej do 30 listopada,

a do koordynowania jej prac został wyznaczony aktor tego teatru, a jednocześnie przewodniczący regionu łódzkiego Andrzej Herder.

39 Postanowiono, że w teatrach na tablicach ogłoszeń zostaną wywieszone komunikaty komisji zakładowych, mówiące o tym, iż „Solidarność” nie będzie broniła członków, którzy pełnią swoje obowiązki pod wpływem alkoholu.

40 AKKS, KKP PT, Sprawozdanie z działalności KKP NSZZ „Solidarność” PT..., k. 71-72; Uchwały krajowej konferencji NSZZ PT „Solidarność, „Biuletyn Informacyjny SPATiF-ZASP” 1980, nr 9, s. $8-10$.

41 AKKS, KKP PT, Sprawozdanie z działalności KKP NSZZ „Solidarność” PT..., k. 72-73; L. Biernacki, A. Kazański, op. cit., s. 49-51; J. Holzer, op. cit., s. 86; Po zakończeniu protestu komitet strajkowy pracowników kultury wystosował apel do społeczeństwa, ludzi kultury, sztuki i nauki oraz dziennikarzy o poparcie ministra kultury w działaniach na rzecz zwiększenia nakładów na kulturę do $2 \%$ dochodu narodowego. KKP PT poparła apel i zwróciła się poprzez regiony do komisji zakładowych o czynne włączenie się w akcję zbierania podpisów. Apel w wielu teatrach odczytywany był ze sceny, a listy z podpisami kierowane były do sejmowej komisji kultury. Przynajmniej w jednym przypadku akcja zbierania podpisów spotykała się z reakcją dyrekcji. W Teatrze im. Wilama Horzycy w Toruniu członek tamtejszego Komitetu Założycielskiego NSZZ „Solidarność, pracownik techniczny Józef Waligórski, za odczytanie apelu ze sceny został ukarany przez dyrektora teatru Marka Okopińskiego zawieszeniem w obowiązkach. Ostatecznie po interwencjach przewodniczącej „Solidarności” w tym teatrze Teresy Wierzbowskiej i toruńskiego MKZ Waligórskiego przywrócono do pracy; AKKS, KKP PT, Notatka przewodniczącej TKZ NSZZ „Solidarność” w Teatrze im. Wilama Horzycy w Toruniu, bd., k. 47-48.

${ }^{42}$ MKiS reprezentował wiceminister Władysław Loranc i dyrektor Departamentu Ekonomicznego Józef Mąka, zaś „Solidarność” reprezentowali Zygmunt Bielawski z Wrocławia i Adam Błażejczak z Łodzi. 
obowiązujący od dnia 1 października dodatek do płacy w wysokości 800 zł dla każdego pracownika zatrudnionego w placówkach podległych ministerstwu. Było to rozwiązanie kompromisowe. We wcześniejszych rozmowach ministerstwo proponowało kwotę $600 \mathrm{zł}$, zaś strona solidarnościowa $1000 \mathrm{zł}$. Według ustalonych w porozumieniu zasad resort kultury miał przekazać poszczególnym zakładom kwoty wynikające z liczby zatrudnionych w nich osób. Podziału kwot miały dokonywać kierownictwa instytucji według zasad zatwierdzonych przez zakładowe organizacje „Solidarności”. Powyższe ustalenia dotyczyły również pracowników instytucji kultury podległych innym resortom ${ }^{43}$.

Tego samego dnia odbyło się posiedzenie Prezydium KKP PT, podczas którego przewodnicząca zdała relację z przebiegu strajku. Ponadto ustalono zasady ordynacji wyborczej, na podstawie której miały odbywać się wybory do władz związku w poszczególnych teatrach ${ }^{44}$. Zgłoszono również propozycję ujednolicenia nazw poszczególnych szczebli sekcji ${ }^{45}$. W ten sposób proces formowania się teatralnej „Solidarności” został zakończony ${ }^{46}$.

\section{Działalność KKP NSZZ „Solidarnośćc" PT}

Przez ponad rok działalności Prezydium teatralnej KKP zebrało się, oprócz omówionego wyżej posiedzenia, jeszcze siedem razy. Na zebraniu 1 grudnia zredagowano pismo do Sekretariatu Krajowej Komisji Porozumiewawczej NSZZ „Solidarność", w którym zawiadamiano o działalności sekcji i składzie jej prezydium oraz upoważniono przewodniczącą i przedstawicieli poszczególnych regionów do reprezentowania jej na zewnątrz. Wstępnie zarejestrowano KKP PT pod numerem 34. Na zebraniu 6 kwietnia przewodnicząca odczytała ramowy projekt statutu wewnętrznego sekcji przygotowany przez gdański MKZ, zastrzegając jednocześnie, że sytuacja $\mathrm{w}$ związku nie sprzyja regulacjom prawnym spraw sekcji ${ }^{77}$. Uznano również, że w celu sprawniejszego opracowania statutu KKP PT nie należy powoływać komisji statutowej, składającej się z przedstawicieli wszystkich regionów,

43 AKKS, KKP PT, Protokół porozumienia Komisji Resortowej MKiS z doraźnym Zespołem ds. Płacowych NSZZ „Solidarność”, 17 XI 1980, k. 49-50.

44 Proces wyboru władz „Solidarności” w poszczególnych teatrach trwał do stycznia $1981 \mathrm{r}$.

45 Dla regionów zaproponowano nazwę Komisja Porozumiewawcza Pracowników Teatru NSZZ „Solidarność" Region - (nazwa miasta), dla komórek zakładowych: Komisja Zakładowa NSZZ „Solidarność w (nazwa teatru). Nie wszyscy przyjęli powyższe propozycje i w praktyce często stosowane były różne nazwy.

46 AKKS, KKP PT, Sprawozdanie z działalności KKP NSZZ „Solidarność” PT..., k. 73.

47 Wiązało się to zapewne $\mathrm{z}$ toczącą się wewnątrz związku dyskusją na temat zasadności istnienia struktur branżowych oraz ich miejsca i roli w działalności „Solidarności”. Na ten temat zob. L. Biernacki, Sekcje branżowe NSZZ „Solidarność” 1980-1981, http://www.wszechnica.solidarnosc.org.pl/?page_id=247 (dostęp: $31 \mathrm{~V}$ 2016). 
lecz powierzyć to zadanie jednemu regionowi. Opracowanie projektu zlecono Komisji Koordynacyjnej Teatrów Regionu Małopolska ${ }^{48}$. Jednak statut, który wyznaczałby program i zakres działania sekcji, nigdy nie został uchwalony ${ }^{49}$.

Działalność teatralnej „Solidarności” kształtowały więc bieżące wydarzenia oraz stające przed nią potrzeby i problemy środowiska, a jej zakres rozciągał się od spraw typowo interwencyjnych, jak na przykład zabiegi w sprawie zbyt niskich przydziałów masła ${ }^{50}$, do spraw zasadniczych, od których miała zależeć przyszłość polskiego teatru. Do tych ostatnich zaliczyć można z pewnością sprawę reformy szkolnictwa teatralnego, co znalazło odzwierciedlenie w uchwale podjętej podczas inaugurującej działalność KKP PT konferencji. 1 grudnia powierzono Jerzemu Stuhrowi zadanie dostarczenia materiałów dotyczących sytuacji w PWST w Krakowie, zaś Teresie Gąsiorowskiej - w filii tej uczelni we Wrocławiu, co miało stanowić podstawę do rozpoczęcia działań w tej sprawie. Informacja ta stanowi jednak ostatni ślad prac nad kwestią szkolnictwa w dokumentach teatralnej „Solidarności” 51 .

Inną sprawą, która wynikała wprost z uchwały podjętej na listopadowej konferencji była kwestia zbiorowego układu pracy. Na początku kwietnia po rozmowie z Andrzejem Gwiazdą przewodnicząca sekcji przekazała informację, że KKP NSZZ „Solidarność" zaleca dalsze wstrzymywanie się od negocjacji z odpowiednimi resortami na temat układów zbiorowych i zachęca do prac konsultacyjnych z załogami. KKP PT zobligowała powołaną przez siebie komisję do wydania komunikatu o zakończeniu prac oraz przekazania projektu układu komisjom zakładowym. Koordynujący prace komisji Andrzej Herder zwrócił uwagę, że opóźnienia w pracach nad projektem wynikają z trudności w nawiązaniu kontaktu z pozostałymi członkami tego gremium. O tych samych problemach Herder wspominał dwa miesiące później. Mimo to Prezydium KKP PT zwróciło się z prośbą o przesłanie projektu do regionów w takim stanie zawansowania, $\mathrm{w}$ jakim się wówczas znajdował. Nawet jeżeli do tego doszło, stało się to u progu okresu urlopowego w teatrach, co z pewnością wydłużyło proces konsultacji nad projektem. Być może z tego właśnie powodu do końca działalności sekcji sprawa zbiorowego układu pracy nie wróciła pod obrady jej prezydium ${ }^{52}$.

Środowisko teatralne zajmowało się również żywo kwestią zniesienia umów sezonowych dla aktorów ${ }^{53}$ i przywrócenia umów na czas nieokreślony. Mimo że

48 Takiej nazwy, wbrew zalecanej nomenklaturze, używał małopolski region KKP PT. W tekście wymiennie będę używał również określenia „Region Małopolska”.

49 AKKS, KKP PT, Sprawozdanie z działalności KKP NSZZ „Solidarność” PT..., k. 87.

${ }^{50}$ Ibidem, k. 77.

51 Ibidem, k. 72.

52 Ibidem, k. 78-81.

53 W sprawie umów sezonowych władze stowarzyszenia uznały swoje poprzednie stanowisko za błędne i poparły działania „Solidarności”, co znalazło odzwierciedlenie w uchwale Prezydium 
od samego początku swojego istnienia teatralna "Solidarność" wypowiadała się przeciwko umowom sezonowym, to dopiero w połowie kwietnia $\mathrm{z}$ inicjatywy Rajmunda Jarosza zostało wystosowane oficjalne pismo w tej sprawie do Departamentu Teatru i Estrady (DTiE) MKiS ${ }^{54}$. „Solidarność” wysunęła dzień 31 maja jako termin załatwienia tej sprawy. Ministerstwo wystąpiło o opinię do ZASP $^{55}$ i mimo zapewnień prezesa Andrzeja Szczepkowskiego, że opinia stowarzyszenia jest zgodna $\mathrm{z}$ żądaniami KKP PT, sprawa utknęła na kilka miesięcy w martwym punkcie ${ }^{56}$. Pewne nadzieje na przyspieszenie prac nad tą kwestią, jak również nad innymi, przewodnicząca sekcji wiązała z zatrudnieniem od 15 października $1981 \mathrm{r}$. prawnika ${ }^{57}$. Mimo to sprawy umów sezonowych nie udało się zakończyć sukcesem ${ }^{58}$.

Specyfika pracy osób zatrudnionych w teatrach, zarówno aktorów, jak i pracowników technicznych, pociągała za sobą konieczność pracy w wolne soboty ${ }^{59}$. W związku z tym KKP PT prowadziła również rozmowy z resortem kultury na temat wynagrodzenia oraz prawnego uregulowania tej kwestii. Trudno oprzeć się wrażeniu, że ministerstwo próbowało rozgrywać w tym przypadku istniejące napięcie pomiędzy teatralną „Solidarnością” a SPATiF-ZASP (o czym szerzej w dalszej części tekstu). Najpierw MKiS uzależniło swoje stanowisko od opinii stowarzyszenia, która miała zostać wydana do 22 września 1981 r., a następnie zaproponowało nowe negocjacje z udziałem ZASP, ZZPKiS ${ }^{60}$ i KKP PT, która nie przyjęła zaproszenia do rozmów. 1 października Halina Winiarska wysyła pismo do ministerstwa $\mathrm{z}$ informacją o rozpoczęciu przygotowań do akcji protestacyjnej oraz pisma do regionów z prośbą o konsultacje z komisjami zakładowymi. Jednocześnie trwały próby uzyskania stanowiska ZASP w tej sprawie, choć według zapewnień Zarządu Głównego ministerstwo nie zwracało się do stowarzyszenia z prośbą o opinię w kwestii wolnych sobót. 16 października KKP PT przystała

Zarządu Głównego ZASP z dnia 25 V 1981 r.; Z obrad Prezydium ZG ZASP, „Biuletyn Informacyjny ZASP-u" 1981, nr 17, s. 1.

${ }^{54}$ AKKS, KKP PT, Sprawozdanie z działalności KKP NSZZ „Solidarność” PT..., k. 80.

55 Podczas Nadzwyczajnego Walnego Zjazdu SPATiF-ZASP w dniach 16-17 kwietnia 1981 r. delegaci opowiedzieli się za rezygnacją z pierwszego członu i przywróceniem dawnej nazwy ZASP, co znalazło wyraz w nowym statucie stowarzyszenia, który uprawomocnił się po kilku miesiącach. ZASP formalnie pozostał stowarzyszeniem twórczym; K.A. Wysiński, Związek Artystów Scen Polskich 1950-1998..., s. 75-77.

56 IT, AZASP, sygn. 3/82, Protokół ze spotkania Prezydium ZG SPATiF-ZASP z przedstawicielami KKP PT NSZZ „Solidarność”, 8 VI 1981, bp.

57 Umowę z prawnikiem i jego honorarium wzięła na siebie komisja zakładowa "Solidarności” w Teatrze Wybrzeże.

58 AKKS, KKP PT, Sprawozdanie z działalności KKP NSZZ „Solidarność” PT..., k. 86.

59 W myśl zawartego w lutym 1981 r. porozumienia, które kończyło trwający od końca grudnia spór „Solidarności” z rządem, każdy pracownik miał prawo do 38 wolnych sobót w roku; L. Biernacki, A. Kazański, op. cit., s. 56-58.

${ }^{60} \mathrm{Na}$ jego czele stała wówczas aktorka Teatru Polskiego we Wrocławiu Irena Remiszewska. 
na propozycję resortu kultury powołania komisji mediacyjnej, w skład której wchodzić mieli mężowie zaufania wyznaczeni przez MKiS i „Solidarność". Termin posiedzenia komisji został wyznaczony na 3 listopada. Trudno stwierdzić, czy to spotkanie w ogóle się odbyło, a tym samym - jaki był jego rezultat. Biorąc jednak pod uwagę wcześniejszą grę na zwłokę ministerstwa i jego wyraźną niechęć do osiągnięcia porozumienia $\mathrm{w}$ tej sprawie, trudno raczej oczekiwać, aby $\mathrm{w}$ tak krótkim czasie, jaki dzielił rozpoczęcie negocjacji od dnia wprowadzenia stanu wojennego, doszło do jakichś zasadniczych ustaleń ${ }^{61}$.

W lutym po raz pierwszy w porządku obrad Prezydium KKP PT pojawił się problem samorządu teatralnego, rozumianego jako jakaś forma kolektywnego zarządzania teatrem. Pojawiły się głosy, że po uzyskaniu przez teatry pełnej autonomii, co miało być efektem ogólnej reformy ekonomicznej i wynikającej z niej reformy teatralnej, związek nie powinien brać udziału we współzarządzaniu. Zgłoszona została również propozycja stworzenia w teatrach swego rodzaju parlamentu pracowniczego - wybieranej w tajnych wyborach przez całość załogi rady pracowniczej. W toku dyskusji zauważono, że takie rozwiązanie kolidowałoby z szerokimi uprawnieniami, jakie planowano przyznać komisjom zakładowym i skazywałoby związki zawodowe na marginalizację. Ze względu na brak jasnej koncepcji postanowiono zwrócić się do regionów o opinię ${ }^{62}$. Na wspólnym posiedzeniu teatralnej „Solidarności” i Prezydium ZG ZASP w dniu 25 października jego członkowie starali się studzić zapędy przedstawicieli KKP PT w kwestii samorządu, argumentując, że nieprzemyślane działania w tej sprawie mogą wywołać bardzo negatywne skutki. Prezes stowarzyszenia Andrzej Szczepkowski stwierdził, iż nie można zbiorowo kierować teatrem, a głos decydujący powinien należeć do indywidualności artystycznych. W tym samym duchu wypowiadał się Aleksander Bardini, który proponował wprowadzenie samorządu jako swego rodzaju eksperymentu na okres próbny. Przedstawiciele KKP PT nie podzielali tych obaw. Według ich koncepcji samorząd miałby sprawować kontrolę ekonomiczną nad placówkami teatralnymi, zgłaszać inicjatywy i dokonywać podziału kompetencji. Ponadto postulowano stworzenie ramowego projektu, który każdy $\mathrm{z}$ teatrów mógłby dostosować do swoich potrzeb ${ }^{63}$. Ciągle były to jednak koncepcje dosyć ogólnikowe. Opracowanie spójnego projektu wymagało dalszych konsultacji i prac, które musiały zostać przerwane 13 grudnia.

Sprawą, która w środowisku teatralnym wywołała wiele kontrowersji i napięć na linii KKP PT - SPATiF-ZASP, była kwestia reformy teatralnej i związana z nią sprawa likwidacji teatrów terenowych. Już w styczniu dwaj przyszli członkowie powołanego w marcu ministerialnego zespołu konsultacyjnego,

${ }^{61}$ AKKS, KKP PT, Sprawozdanie z działalności KKP NSZZ „Solidarność” PT..., k. 86-87.

62 Ibidem, k. 76.

${ }^{63}$ IT, AZASP, sygn. 3/82, Protokół ze spotkania Prezydium ZG ZASP z przedstawicielami KKP PT NSZZ „Solidarność”, 25 X 1981, bp. 
Andrzej Szczepkowski i Zygmunt Hübner, w opracowaniach sporządzonych na potrzeby raportu o stanie kultury polskiej ${ }^{64}$ wspominali o takiej możliwości. Szczepkowski pisał: „Należy wreszcie z największą ostrożnością i troskliwością przeanalizować zasadność istnienia tych zawodowych placówek teatralnych w niektórych punktach geograficznych naszego kraju, których nieodpowiedzialna [i] niekontrolowana działalność przynosi straty zarówno miejscowemu społeczeństwu jak i polskiej kulturze teatralnej. Tam, gdzie istnieje autentyczne [podkr. A.S.] zapotrzebowanie społeczne na teatr należy w takich wypadkach szukać rozsądnego rozwiązania w właściwie zorganizowanych impresariatach"65. W tekście Hübnera możemy przeczytać, że „reforma administracyjna kraju [...] spowodowała nie tyle dynamiczny, co żywiołowy rozwój teatru. Lokalne ambicje doprowadziły do powstawania nowych, stałych teatrów (Płock, Legnica) lub tworzenia dwóch samodzielnych jednostek tam, gdzie przedtem istniał jeden teatr o dwóch scenach (Olsztyn-Elbląg, Kielce-Radom, Koszalin-Słupsk, Szczecin - rozdział teatrów Polskiego i Współczesnego). Wynikiem tych działań był stopniowy spadek poziomu teatrów terenowych, które wciąż nie są w stanie skompletować w pełni profesjonalnych zespołów artystycznych i muszą posługiwać się $\mathrm{w}$ dużej mierze amatorami przyuczonymi do zawodu $\mathrm{z}$ braku aktorów wykwalifikowanych"66. Dalej Hübner wspominał o bardzo kosztownych budowach nowych gmachów teatralnych w Opolu i Elblągu przy jednoczesnym braku środków finansowych na bardzo potrzebne remonty w czołowych placówkach warszawskich i krakowskich. Kończąc omawianie tego zagadnienia, pisał: „Jest to problem niejednokrotnie dyskutowany: czy nie należałoby zmniejszyć ilości teatrów, drastycznie ograniczyć ich działalność objazdową. Szukać rozwiązania raczej w dowożeniu widzów do teatru niż teatru do widzów. Zdania na ten temat są w środowisku teatralnym podzielone. Zmniejszenie ilości teatrów to zmniejszenie ilości miejsc pracy, a w konsekwencji obawa bezrobocia wśród aktorów, co najmniej zaś zaostrzonej konkurencji. Ograniczenie objazdu to ograniczenie zarobków, uzyskiwanych wprawdzie kosztem wielkiego wysiłku i niewygód. Dlatego Zarząd Stowarzyszenia nigdy nie występował z takim postulatem, aczkolwiek wielu członków Zarządu uważa go za słuszny" ${ }^{\text {67. }}$. W podobnym tonie wypowiadał się w obecności kierownika Wydziału Kultury KC Mieczysława Wojtczaka i wiceministra kultury Władysława Loranca prezes SPATiF Gustaw Holoubek oraz kilku innych mówców podczas narady teatralnej zorganizowanej przez

\footnotetext{
${ }^{64}$ Raport taki był przygotowywany przez Komitet Porozumiewawczy Stowarzyszeń Twórczych i Naukowych.

65 A. Szczepkowski, Analiza, wnioski i postulaty, „Biuletyn Informacyjny SPATiF-ZASP” 1981, nr 5, s. 3 .

${ }^{66}$ Z. Hübner, Sytuacja teatru, ibidem, s. 4.

${ }^{67}$ Ibidem, s. 5.
} 
stowarzyszenie w dniach 2-3 marca, a więc kilkanaście dni przed rozpoczęciem działalności zespołu ministerialnego ${ }^{68}$.

Jak widać powstanie „Solidarności” nie zmieniło, jak w przypadku umów sezonowych, stanowiska prominentnych przedstawicieli SPATiF. Przyznać trzeba, że nie było ono pozbawione podstaw. Sieć teatralna była nadmiernie rozbudowana. Władze, tworząc kolejne placówki, miały na uwadze przede wszystkim korzyści propagandowe. Było to jedno z narzędzi służących do ich legitymizacji. Realia ekonomiczne czy interes artystyczny odgrywał tu rolę drugorzędną. Sprzęgało się to ze swoistym snobizmem lokalnych władz i elit kulturalnych. Teatr bowiem był tą instytucją kulturalną, która dużo bardziej niż inne nobilitowała miasto, poprzez posiadanie własnego środowiska artystycznego ${ }^{69}$.

Pod koniec marca przewodnicząca sekcji Halina Winiarska otrzymała telefoniczne zaproszenie od dyrektora DTiE MKiS Henryka Bieniewskiego do udziału w pracach zespołu ${ }^{70}$. Ze względu na jej obowiązki w macierzystym teatrze, w pierwszym posiedzeniu owego zespołu, które odbyło się 28 marca, KKP PT reprezentowali Jerzy Stuhr i Andrzej Zaorski. Ministerstwo zaproponowało m.in. likwidację ok. 15 teatrów prezentujących najniższy poziom artystyczny i utworzenie $\mathrm{w}$ ich miejsce scen impresaryjnych ${ }^{71}$, które zapraszałyby najlepsze przedstawienia $\mathrm{z}$ innych teatrów. Powstała $\mathrm{w}$ ten sposób grupa bezrobotnych aktorów utworzyłaby rezerwę artystyczną z gażami wypłacanymi początkowo przez MKiS, a następnie przez powołaną w tym celu instytucję pod nazwą Krajowa Agencja Artystyczna. Urzędnicy ministerstwa argumentowali, iż tańszym rozwiązaniem byłoby utrzymywanie pozostających bez pracy aktorów niż dotowanie placówek teatralnych, w których są zatrudnieni ${ }^{72}$.

Na posiedzeniu Prezydium KKP PT 6 kwietnia została podjęta decyzja, że jej przedstawiciele $\mathrm{w}$ ministerialnym zespole mają status obserwatorów bez prawa podejmowania decyzji ${ }^{73}$. Podczas kolejnego spotkania w MKiS, które odbyło się 17 kwietnia, Halina Winiarska poprosiła dyrektora DTiE o przedstawienie

68 Archiwum Akt Nowych w Warszawie (dalej: AAN), Komitet Centralny PZPR (dalej: KC PZPR), sygn. LVI-413, Informacja i uwagi o naradzie środowiska teatralnego w dniach 2-3 III 1981, bp.

${ }^{69}$ A. Wallis, op. cit., s. 64.

70 W pracach zespołu brali udział m.in. prezes SPATiF-ZASP (od kwietnia 1981 r.) Andrzej Szczepkowski, przewodniczący Rady Artystycznej stowarzyszenia, a zarazem dyrektor Teatru Polskiego w Warszawie Kazimierz Dejmek, dyrektor Teatru Powszechnego w Warszawie Zygmunt Hübner, dyrektor Teatru Nowego w Poznaniu Izabela Cywińska, dyrektor administracyjny Teatru Dramatycznego w Warszawie Mieczysław Marszycki, przewodnicząca ZZPKiS Irena Remiszewska; H. Bieniewski, Z deszczu pod rynnę, Warszawa 2001, s. 195.

${ }^{71}$ Miały to być tzw. ośrodki teatralne, na które składałyby się budynki teatralne wraz z kierownictwem artystycznym bez zespołu aktorskiego.

72 AKKS, KKP PT, Sprawozdanie z działalności KKP NSZZ „Solidarność” PT..., k. 77-78, 84; H. Bieniewski, op. cit., s. 196.

73 AKKS, KKP PT, Sprawozdanie z działalności KKP NSZZ „Solidarność” PT..., k. 78. 
szczegółowego raportu o stanie teatrów w Polsce. Przesłany przez ministerstwo dokument na kolejnym spotkaniu 7 maja został poddany krytyce. Głównym zarzutem, jaki podnoszono, była jego niezgodność ze stanem faktycznym. Przekazana została również krytyczna wobec planów resortu opinia Komisji Koordynacyjnej Teatrów Regionu Małopolska. Na ostatnim przed wakacjami posiedzeniu zespołu przewodnicząca teatralnej „Solidarności” zwróciła się z prośbą o dostarczenie sekcji przez ministerstwo wszystkich opracowanych propozycji planowanej reformy, w celu przeprowadzenia szerokich konsultacji w tej sprawie ${ }^{74}$.

Kwestia ta ponownie nabrała tempa jesienią. Na wspomnianym już tutaj wspólnym zebraniu 25 października przedstawiciele KKP PT i ZG ZASP zgodzili się co do potrzeby powołania wspólnej komisji, która zajmie się przygotowaniem raportu o stanie teatrów. Ponadto wskazano na konieczność jak najszybszego opracowania własnego projektu reformy teatralnej ${ }^{75}$. Jednak ani projekt, ani wspomniana wyżej komisja nigdy nie powstały. Pogłębiający się od kilku miesięcy rozłam w sekcji teatralnej, którego jedną z głównych przyczyn był właśnie stosunek do SPATiF-ZASP ${ }^{76}$ i roli jego przedstawicieli $\mathrm{w}$ ministerialnym zespole, z pewnością temu nie sprzyjał. Tymczasem $\mathrm{w}$ listopadzie ministerstwo przedstawiło ostateczne propozycje reformy ${ }^{77}$.

Słabość rozdzieranej wewnętrznym konfliktem KKP PT spowodowała, że inicjatywę w tej sprawie przejął ZASP, otwarcie już wchodząc w rolę związku zawodowego. Powtórzyła się sytuacja sprzed 1980 r., z tą różnicą, że w roli ZZPKiS występowała teraz teatralna „Solidarność". Zarząd Główny stowarzyszenia powołał 23 listopada Zespół Społeczny ds. Prac nad Reformą Teatralną, który miał m.in. opracować zasady reformy i opiniować projekty innych organizacji i instytucji. W uchwale znalazł się również zapis, że zespół „nawiąże bezpośrednie kontakty robocze $\mathrm{z}$ właściwymi organami NSZZ «Solidarność» celem zapewnienia

${ }^{74}$ Ibidem, k. 84-86.

75 IT, AZASP, sygn. 3/82, Protokół ze spotkania...., bp.

${ }^{76} \mathrm{~W}$ tym miejscu sygnalizuję jedynie problem, który zostanie szczegółowo omówiony w dalszej części tekstu.

77 Ministerstwo proponowało m.in. wprowadzenie nowego systemu finansowania teatrów, który uwzględniałby koszty stałe i zmienne. Dotacje przedmiotowe pokrywałyby wszystkie koszty z wyjątkiem funduszu płac, na który miała być przeznaczona dotacja podmiotowa. Jej uzyskanie z kolei uzależniano od wpływów kasowych, czyli od frekwencji. Dla teatrów w większych ośrodkach minimum frekwencji ustalono na $70 \%$, zaś w ośrodkach mniejszych na 50\%. Teatry, które nie osiągną tych norm, a tym samym nie otrzymają dotacji podmiotowej, miały otrzymać w pierwszym roku kredyt bankowy. Placówka, która w następnym roku ponownie nie osiągnęłaby wskaźników frekwencji miała ulec likwidacji. Aktorzy, którzy w wyniku likwidacji teatru pozostaliby bez pracy, otrzymywaliby wsparcie finansowe $\mathrm{z}$ funduszu funkcjonującego przy ZASP lub przy ministerstwie. Zmiany miały dotyczyć również systemu wynagradzania. Wynagrodzenie aktora miało się składać z części stałej (gaży) i części zmiennej - wynagrodzenia za każdy występ. Likwidacji ulegały normy; IT, AZASP, sygn. 3/82, Protokół z posiedzenia Prezydium ZG ZASP, 16 XI 1981, bp. 
rzeczywistego współdziałania obu organizacji ${ }^{78} \mathrm{w}$ pracach nad reformą teatralną"79. Prace zespołu zostały przerwane wraz z zawieszeniem ZASP po wprowadzeniu stanu wojennego ${ }^{80}$.

KKP PT brała również udział w projektach mających na celu uregulowanie spraw kultury w skali całego związku. 15 kwietnia z inicjatywy KKP NSZZ „Solidarność" odbyło się spotkanie przedstawicieli sekcji działających w obszarze kultury $^{81}$. W jego trakcie nie zapadły żadne rozstrzygnięcia i zakończyło się ono propozycją odbycia posiedzenia w szerszym gronie. Podczas kolejnego zebrania z udziałem przedstawiciela KKP związku sekcję teatralną reprezentowali Halina Winiarska i Rajmund Jarosz. W jego trakcie członek Komisji Ekspertów ds. Zarządzania i Finansowania Kultury Mirosław Borusiewicz zaproponował powołanie Ogólnopolskiej Komisji Koordynacyjnej Pracowników Kultury ${ }^{82}$, działającej według regulaminu zatwierdzonego przez KKP. W skład komisji miałoby wchodzić po dwóch przedstawicieli każdej sekcji na dwuletnią kadencję. W założeniach miała stanowić organ konsultacyjny dla KKP, z możliwością upoważnienia do samodzielnego działania. Po burzliwej dyskusji projekt powołania komisji został odrzucony. Przeciwko głosowała również przewodnicząca sekcji teatralnej. Do kolejnych prób koordynacji działań nie doszło ${ }^{83}$. Poszczególne sekcje działały na własną rękę, bez, jak się wydaje, większego wsparcia władz związku.

W dniach 5-10 września i 26 września-7 października $1981 \mathrm{r}$. odbył się w Gdańsku I Krajowy Zjazd Delegatów NSZZ „Solidarność. Choć sprawy teatralne występowały w trakcie jego obrad jedynie w szerszym kontekście kultury jako całości, wśród delegatów znalazło się kilkoro przedstawicieli środowiska teatralnego. Najaktywniejszym z nich był reprezentujący Region Gdański Szymon Pawlicki, który oprócz działalności na innych zjazdowych polach zgłosił odczytany 3 października apel, w którym czytamy m.in.: „Punkt 3 porozumienia gdańskiego ${ }^{84}$ nie został dotąd zrealizowany. Jeżeli do końca października br.

${ }^{78}$ Warte podkreślenia jest użycie określenia „właściwe organy” bez wymienienia z nazwy KKP PT oraz sformułowania „rzeczywistego współdziałania obu organizacji”, które mogło sugerować, że dotychczasowa współpraca miała charakter iluzoryczny.

79 Powołanie Zespołu Społecznego ds. Prac nad Reforma Teatralną, „Biuletyn Informacyjny ZASP-u” 1981, nr 23, s. 3-4.

80 Ibidem.

81 Takich sekcji było 11 .

${ }^{82}$ Według Haliny Winiarskiej w obliczu lawinowo rosnącej liczby powstających sekcji branżowych, powołaniu komisji towarzyszyła chęć ochrony mniejszych sekcji, kontroli ich działań oraz zrzucenia z KKP choćby częściowego ciężaru koordynowania sekcjami działającymi w obszarze kultury.

${ }^{83}$ AKKS, KKP PT, Sprawozdanie z działalności KKP NSZZ „Solidarność” PT..., k. 79-80.

84 Trzeci postulat MKS w Stoczni Gdańskiej w sierpniu 1980 r. brzmiał: „Przestrzegać zagwarantowanej w Konstytucji PRL wolności słowa, druku i publikacji, a tym samym nie represjonować niezależnych wydawnictw oraz udostępnić środki masowego przekazu dla wszystkich wyznań". W podpisanym 31 sierpnia przez MKS i Komisję Rządową porozumieniu zapisano odnośnie 
Radiokomitet nie będzie podporządkowany społecznej kontroli, zrezygnujemy ze współpracy z Telewizją Polską. Stracimy na tym parę złotówek, wynikających z proponowanych nam umów o dzieło, zyskamy poczucie godności i świadomość spełnionego obowiązku wobec idei «Solidarności». Naszą wiedzę i talent oddajemy społeczeństwu, niech jego głos określa naszą wartość"85. Apel Pawlickiego został poparty dwa dni później przez prezesa Zarządu Głównego Związku Polskich Artystów Plastyków (ZPAP), w trakcie jego wystąpienia po podpisaniu porozumienia pomiędzy NSZZ „Solidarność” a ZPAP ${ }^{86}$.

Reprezentujący Region Mazowsze Kazimierz Kaczor zasiadał w zespole X (Edukacja i kultura narodowa), sekcji 3 Komisji Programowej. 5 października $\mathrm{w}$ jej imieniu referował dwa projekty: Deklaracji Zjazdu w sprawie kultury narodowej i Deklaracji Zjazdu w sprawie komitetów obrony więzionych za przekonania. 7 października Kaczor zaprezentował drugą wersję pierwszej deklaracji, która tego samego dnia została ostatecznie przyjęta. Oprócz Pawlickiego i Kaczora środowisko teatralne reprezentowane było na zjeździe przez Irenę Telesz-Burczyk, delegatkę Regionu Warmińsko-Mazurskiego, oraz Halinę Mikołajską i Jerzego Markuszewskiego, delegatów Regionu Mazowsze. W imieniu ZASP w czasie II tury zjazdu wystąpił wiceprezes stowarzyszenia Stanisław Brejdygant ${ }^{87}$.

\section{Konflikt ze SPATiF-ZASP}

Mimo że większość aktorów należących do „Solidarności” była jednocześnie członkami SPATiF-ZASP, relacje pomiędzy tymi dwiema organizacjami nie należały do najlepszych. Pierwsze symptomy późniejszych trudności zaznaczyły się już podczas nadzwyczajnego zjazdu stowarzyszenia, który odbył się 29 września 1980 r. ${ }^{88}$ Wśród powszechnego entuzjazmu, wywołanego faktem powstania "Solidarności”, być może nie do końca uświadamiano sobie sens słów gościa zjazdu, przedstawiciela Regionu Mazowsze Janusza Ściskalskiego, który stwierdził: „uważacie, że ZASP będzie dla Was autonomiczną organizacją twórczą, ale jednocześnie Związek Zawodowy pozostanie na drugim planie. [...] Ja ze swej strony mam obawy i mówię to w imieniu Zarządu «Mazowsze».

do trzeciego postulatu, że działalność prasy, radia, telewizji i wydawnictw winna podlegać społecznej kontroli. Porozumienie nie precyzowało, w jaki sposób miałaby ona być sprawowana; http://www.wszechnica.solidarnosc.org.pl/?page_id=2906 (dostęp: 06 VI 2016).

${ }^{85}$ I Krajowy Zjazd Delegatów NSZZ „Solidarność”..., s. 221.

${ }^{86}$ Ibidem, s. 522.

${ }^{87}$ Ibidem, s. 526-529, 865-867.

${ }^{88}$ Podczas zjazdu prezes Gustaw Holoubek zgłosił wniosek o przekształcenie SPATiF-ZASP w niezależny Związek Artystów Scen Polskich o charakterze twórczym. Jedna z dwóch uchwał zjazdu mówiła o reaktywowaniu ZASP w ramach NSZZ „Solidarność” w momencie jej rejestracji. 
Chciałbym, żebyście Państwo tę sprawę rozważyli, żeby nie powstała organizacja ZASP, jako ta, która stwarza dla nas zagrożenie, bo naprawdę - proszę Panów - chodzi tu o sprawy ważne. Jeśli powstają dwie organizacje, to budzi naszą wątpliwość"s9.

Podczas swojego pierwszego posiedzenia Prezydium KKP PT podkreśliło konieczność reaktywowania ZASP jako stowarzyszenia twórczego i wyraziło potrzebę współpracy z nim na terenie teatrów ${ }^{90}$. Kilka dni później, 24 listopada, odbyło się spotkanie przedstawicieli Regionu Mazowsze KKP PT ${ }^{91}$ i członków Oddziału Warszawskiego SPATiF. W jego trakcie postanowiono powołać Komisję ds. współpracy z „Solidarnością”, w celu zapewnienia dobrej komunikacji między obiema organizacjami. Na przedstawiciela Oddziału Warszawskiego do spraw łączności z "Solidarnością” został wybrany Damian Damięcki. Przedstawiciel związku miał zostać powołany w najbliższym czasie. Podjęto również wspólną uchwałę, w której była mowa o konieczności współpracy oraz poparciu dążeń stowarzyszenia do przekształcenia się w ZASP ${ }^{92}$. Porozumienie to miało stanowić ewentualną propozycję wzorcową dla porozumień zawieranych przez inne regiony $z$ odpowiednimi oddziałami stowarzyszenia. Prezydium KKP PT stanęło na stanowisku, że decyzje w tej sprawie powinny być podejmowane lokalnie. W przypadku zawarcia porozumień przez wszystkie regiony KKP PT zobowiązywała się podpisać porozumienie z ZG SPATiF ${ }^{93}$.

Do12 stycznia, kiedy odbyło się wspólne posiedzenie Prezydium KKP PT i ZG SPATiF, spośród ośmiu regionów lokalne porozumienia z oddziałami SPATiF podpisały jedynie cztery: Mazowsze, Wielkopolska, Ziemia Łódzka i Pomorze Zachodnie. Region Gdański nie zawarł takiego porozumienia, gdyż obszar jego działania nie pokrywał się z obszarem działania gdańskiego oddziału stowarzyszenia. Jednakże 5 stycznia odbyło się zebranie tego regionu, w którego trakcie stwierdzono, że współpraca pomiędzy komisjami zakładowymi w poszczególnych teatrach a kołami SPATiF przebiega bezkonfliktowo. Nie wyrażono również sprzeciwu wobec ewentualnego porozumienia z ZG SPATiF. Zostało ono podpisane na wspomnianym wyżej styczniowym spotkaniu władz obu organizacji ${ }^{94}$. Pod koniec lutego swoje zastrzeżenia co do jego zasadności zgłosił na forum Prezydium KKP PT przedstawiciel Regionu Małopolska. Nieco później okazało się również, że sekcja teatralna nie miała prawa zawierać porozumienia ze SPATiF

\footnotetext{
${ }^{89}$ Cyt. za K.A. Wysiński, Związek Artystów Scen Polskich 1950-1998..., s. 71-72.

90 AKKS, KKP PT, Sprawozdanie z działalności KKP NSZZ „Solidarność” PT..., k. 73-74.

${ }^{91} \mathrm{~W}$ dalszej części tekstu używam tego określenia wymiennie z oficjalną nazwą Tymczasowa Komisja Porozumiewawcza Pracowników Teatru NSZZ „Solidarność” Region Mazowsze.

92 Spotkanie SPATiF-,,Solidarność” w Warszawie, „Biuletyn Informacyjny SPATiF-ZASP” 1980, nr 9, s. 5-8; K.A. Wysiński, Związek Artystów Scen Polskich 1950-1998..., s. 72.

93 AKKS, KKP PT, Sprawozdanie z działalności KKP NSZZ „Solidarność” PT..., k. 74.

${ }^{94}$ Łącznikiem z ramienia KKP PT do kontaktów ze SPATiF został Andrzej Zaorski.
} 
bez uprzedniej zgody KKP NSZZ „Solidarność”, uzależnionej od pozytywnego rezultatu analizy formalno-prawnej projektu porozumienia ${ }^{95}$.

Podczas posiedzenia Prezydium KKP PT w dniu 6 kwietnia omawiana była strategia działania sekcji w związku ze zbliżającym się kolejnym nadzwyczajnym zjazdem SPATiF. Pojawiły się głosy oskarżające stowarzyszenie o brak deklarowanego współdziałania i nierealizowanie w praktyce zawartego porozumienia. W związku z tym postanowiono, że wystąpienie na zjeździe przedstawiciela teatralnej „Solidarności” powinno być utrzymane w zdecydowanym tonie. Dopiero wyjaśnienia złożone przez Damiana Damięckiego ostudziły nieco nastroje i zdecydowano ostatecznie wystąpić jedynie z kurtuazyjnym pozdrowieniem ${ }^{96}$.

Mimo to atmosfera we wzajemnych relacjach coraz bardziej się psuła. Niewątpliwie najbardziej przyczyniał się do tego wspomniany już tutaj udział przedstawicieli SPATiF-ZASP $\mathrm{w}$ ministerialnym zespole ds. reformy teatrów i opinia o tym, jaka rozpowszechniła się $\mathrm{w}$ środowisku teatralnym. Wobec uczestniczących w tym zespole członków SPATiF pojawiły się zarzuty o wspieranie, a nawet inicjowanie pomysłów dotyczących likwidacji pewnej liczby teatrów terenowych. Reakcją władz stowarzyszenia na stawiane im zarzuty był komunikat z 25 maja, w którym stwierdzano: „W związku z szalejącymi pogłoskami na temat działalności Komisji do Spraw Reformy Teatralnej, powołanej przez DTiE MKiS i w związku z rozpowszechnianymi przez tenże departament informacjami i materiałami, które mogłyby niesłusznie sugerować udział ZASP-u w ich opracowywaniu, oświadczamy co następuje: ZASP nie podejmował i nie zamierza podejmować żadnych prac i decyzji, bez pełnego porozumienia z KKP NSZZ «Solidarność Pracowników Teatru i bez obopólnej akceptacji projektów. Jednocześnie komunikujemy, iż wyż. wym. Komisja, złożona z przedstawicieli całego naszego środowiska, $\mathrm{z}$ uwzględnieniem KKP NSZZ «Solidarność» P.T. i Z.G. ZASP, stanowi w obecnym kształcie jedynie rodzaj forum dyskusyjnego i nie podejmuje żadnych wiążących decyzji”"97. Zwrócono się również do KKP PT z propozycją odbycia spotkania, które miałoby na celu wyjaśnienie narosłych nieporozumień ${ }^{98}$.

Władze stowarzyszenia znalazły się w kłopotliwej sytuacji. Zapewne w pamięci wielu osób pozostawały chociażby, przytaczane wyżej, enuncjacje Andrzeja Szczepkowskiego i Zygmunta Hübnera czy wystąpienia Gustawa Holoubka, zarówno te sprzed powstania „Solidarności”, jak i te późniejsze ${ }^{99}$. Ministerstwo, głuche do tej pory na postulaty czołowych przedstawicieli SPATiF, teraz przejmowało ich argumentację. Tym samym mogło powstać wrażenie, że to

\footnotetext{
95 Ibidem, k. 77-80.

96 Ibidem, k. 79.

97 Z obrad Prezydium ZG ZASP, „Biuletyn Informacyjny ZASP-u” 1981, nr 17, s. 1.

98 IT, AZASP, sygn. 3/82, List prezesa ZASP do KKP NSZZ „Solidarność” PT, 25 V 1981, bp.

99 Zob. AAN, KC PZPR, LVI-413, Informacja i uwagi o naradzie środowiska teatralnego..., bp.
} 
właśnie władze stowarzyszenia inspirowały ministerstwo. Być może było to świadome działanie, obliczone na pogłębienie podziałów w środowisku i osłabienie jego pozycji w toczonych $\mathrm{z}$ MKiS negocjacjach. Jeśli tak było, to jak pokażą późniejsze wydarzenia, obrana przez ministerialnych urzędników taktyka przynosiła rezultaty.

Wspólne zebranie odbyło się 8 czerwca i miało bardzo burzliwy przebieg. Od samego początku zdominowała go sprawa statutu ZASP. Przedstawiciele „Solidarności” domagali się zmiany kilku punktów, które ich zdaniem mogły świadczyć o chęci odgrywania przez stowarzyszenie roli związku zawodowego, co było zarezerwowane dla „Solidarności”. Druga strona podkreślała swoją lojalność wobec związku i argumentowała, że statut został uchwalony przez walny zjazd i tylko on może go zmienić. Wobec tego przedstawiciel KKP PT Szymon Pawlicki ${ }^{100}$ odczytał uchwałę KKP NSZZ "Solidarność” z 18 maja ${ }^{101}$. Znalazły się w niej m.in. następujące stwierdzenia: „Po przeanalizowaniu sytuacji środowiska teatralnego KKP NSZZ «Solidarność» [...] w pełni popiera inicjatywę tworzenia Stowarzyszeń Twórczych pełniących rolę forum artykułującego sprawę dotyczącą specyfiki zawodu i inicjatyw twórczych wąskiej grupy pracowników teatru $\mathrm{z}$ wyłączeniem uprawnień decyzyjnych $\mathrm{w}$ sprawach pracowniczych dotyczących całej załogi. [...] KKP stwierdza, że niektóre paragrafy statutu ZASP przyznają mu kompetencje wkraczające w zakres działalności Związków Zawodowych i Samorządów Pracowniczych. Stan ten tworzy strukturę hybrydową, będącą zarodkiem konfliktu w środowisku teatralnym, stwarzającą możliwość działań chaotycznych, zakłócających działalność NSZZ «Solidarność» z intencją rozbicia naszego Związku. [...] KKP popiera zastrzeżenia zgłoszone przez Komisję Koordynacyjną teatrów Regionu Małopolska wobec porozumienia z dnia 12.I.1981 roku [...] Przyjęty tryb równego parytetu narusza nasze prawa i godzi w niezależność NSZZ «Solidarność»"102.

Po odczytaniu uchwały zarządzono przerwę w obradach, w trakcie której przedstawiciele strony solidarnościowej podjęli w głosowaniu decyzję o zerwaniu styczniowego porozumienia ze SPATiF-ZASP. Po wznowieniu obrad i ogłoszeniu stanowiska KKP PT ujawniły się rozbieżności pomiędzy przedstawicielem Regionu Małopolska Rajmundem Jaroszem a reprezentującym Region Mazowsze

${ }^{100} \mathrm{Na}$ liście obecności obok nazwiska Pawlickiego widnieje informacja, że był on koordynatorem ds. kultury KKP NSZZ „Solidarność”.

101 Wcześniej dokument został odczytany 30 maja na zebraniu w gdańskim Oddziale ZASP jako uchwała przygotowana przez MKZ Małopolska (zapewne z inspiracji Komisji Koordynacyjnej Teatrów Regionu Małopolska). Jej istnienie i treść nie mogły więc być zaskoczeniem dla władz ZASP. Kontrowersje dotyczyły natomiast faktu uchwalenia przez KKP związku dokumentu przygotowanego tylko przez jeden region, bez konsultacji z pozostałymi; AKKS, KKP PT, Sprawozdanie z działalności KKP NSZZ „Solidarność” PT..., k. 81-82.

${ }^{102}$ Komunikat o spotkaniu ZASP-,,Solidarność”, „Biuletyn Informacyjny ZASP-u” 1981, nr 20, s. 1-2; IT, AZASP, sygn. 3/82, Uchwała KKP NSZZ „Solidarność, 18 V 1981, bp. 
Włodzimierzem Brühlem, który zaprotestował przeciwko podejmowaniu przez KKP uchwał w oparciu o opinię jednego regionu i oświadczył, że zwróci się do władz Regionu Mazowsze związku o wyrażenie wotum nieufności w stosunku do działań KKP NSZZ „Solidarność”103. Trzy dni później odbyło się spotkanie Zarządu Oddziału Warszawskiego ZASP z Prezydium Tymczasowej Komisji Porozumiewawczej Pracowników Teatru NSZZ „Solidarność” Region Mazowsze, podczas którego utrzymano w mocy porozumienie o współpracy z 24 listopada i zapowiedziano działania mające na celu jego doprecyzowanie. W wydanym oświadczeniu podkreślono konieczność utrzymania jedności środowiska teatralnego ${ }^{104}$. Dzień później z protestem i prośbą o interwencję w sprawie uchwały wystąpili do władz teatralnej „Solidarności” Regionu Mazowsze członkowie związku zasiadający w ZG ZASP ${ }^{105}$. Prośba została spełniona w postaci dwóch, podjętych w połowie czerwca, uchwał. W jednej z nich stwierdzano, że „Nie widzimy niebezpieczeństwa wkraczania ZASP-u w kompetencje związku zawodowego, tym bardziej że [...] [statut ZASP] wyraźnie stwierdza konieczność ścisłej współpracy ze Związkiem Zawodowym a zwłaszcza z NSZZ «Solidarność». [...] Nie zgadzamy się z punktem [...], w którym krytykuje się tryb równego parytetu we współpracy z ZASP-em i NSZZ «Solidarność». Zwracamy uwagę, że chodzi w tym wypadku o demokratyczną współpracę dwóch równoprawnych instytucji: związku zawodowego i stowarzyszenia twórczego bez względu na ich liczebność"106.

Spotkanie przedstawicieli komisji zakładowych i kół stowarzyszenia odbyło się również w Gdańsku. W sprawozdaniu z tego posiedzenia czytamy: „W parogodzinnej dyskusji wyjaśniono kilka spornych punktów, jednogłośnie uznano konieczność ścisłej współpracy i porozumienia. Wiele niepokoju wzbudziła uchwała MKZ-Małopolska zatwierdzona przez KKP w wyniku niekonsultowanej opinii, wyrażonej przez Kol. Szymona Pawlickiego ${ }^{107}$ - uchwała,

103 IT, AZASP, sygn. 3/82, Protokół ze spotkania Prezydium ZG ZASP z przedstawicielami KKP PT NSZZ „Solidarność”, 8 VI 1981, bp.

104 Oświadczenie Oddziału Warszawskiego ZASP i „Solidarności”, „Biuletyn Informacyjny ZASP-u” 1981, nr 20, s. 3.

105 IT, AZASP, sygn. 3/82, Pismo do TKP PT NSZZ „Solidarność” Region Mazowsze, 12 VI 1981, bp.

106 Stanowisko TKP Pracowników Teatru Region Mazowsze, „Biuletyn Informacyjny ZASP-u” 1981, nr 21, s. 5-6.

107 Działalność Szymona Pawlickiego już wcześniej budziła kontrowersje. W piśmie z 14 marca do gdańskiego MKZ Komisja Porozumiewawcza Instytucji Artystycznych i Środowisk Kulturalnych Województwa Gdańskiego stwierdzała: „Uważamy Szymona Pawlickiego za przedstawiciela całego, licznego środowiska pracowników kultury województwa gdańskiego w MKZ-NSZZ Solidarność w Gdańsku, działającego w ścisłym porozumieniu z Komisją i korzystającego z jej mandatu. Kategorycznie sprzeciwiamy się obarczaniem [sic!] Szymona Pawlickiego obowiązkami wykraczającymi poza ramy wyznaczone tym mandatem - a zwłaszcza poza zagadnienia ściśle dotyczące spraw kultury. [...] Aby problemy wielotysięcznej rzeszy pracowników kultury naszego regionu zyskały kompetentne przedstawicielstwo 
podważająca w swej wymowie porozumienie: ZASP-«Solidarność», oraz ingerująca w statut ZASP"108.

Nie wiemy, jak podczas spotkania 8 czerwca głosowali przedstawiciele poszczególnych regionów, ale z późniejszych reakcji można wnioskować, że za współpracą z ZASP opowiadały się Region Mazowsze i Region Gdański. Można sądzić, że pozostałe regiony albo zachowały postawę neutralną $\mathrm{w}$ tym sporze, albo skłaniały się ku stanowisku Regionu Małopolska.

Sprawa na tym się nie zakończyła. Przewodnicząca sekcji teatralnej zwróciła się do KKP o udostępnienie sygnowanej przez nią uchwały MKZ Małopolska ${ }^{109}$. W odpowiedzi nadeszło oświadczenie, w którym Sekretariat KKP informował, iż „uchwała MKZ Małopolska podjęta w dniu 18.V.81 r. nie jest uchwałą Krajowej Komisji Porozumiewawczej NSZZ «Solidarność». Jednocześnie Sekretariat KKP NSZZ «Solidarność» informuje, że sprawa teatrów w ogóle nie stawała na posiedzeniach Krajowej Komisji Porozumiewawczej"110. Oświadczenie zostało przekazane do wiadomości ZG SPATiF. Poczynania Haliny Winiarskiej zostały ocenione przez Sekcję Kultury MKZ Małopolska w teleksie wysłanym do Lecha Wałęsy jako działania mające na celu kompromitację władz związku i podważenie autorytetu sekcji teatralnej i MKZ Małopolska. Pod koniec czerwca do Winiarskiej dotarły za pośrednictwem Sekretariatu KKP uchwały przedstawicieli załóg sześciu teatrów: Teatru Starego w Krakowie oraz teatrów w Słupsku, Jeleniej Górze, Wałbrzychu, Legnicy i Gdyni. Oceniano w nich krytycznie działalność KKP PT, domagano się przeprowadzenia wyborów do władz sekcji do 30 września oraz stawiano zarzut niedoinformowania środowiska ${ }^{111}$.

Czerwcowe wspólne zebranie władz KKP PT i ZG ZASP stało się momentem zwrotnym w historii teatralnej „Solidarności”. Narastające napięcia w relacjach $\mathrm{z}$ władzami stowarzyszenia przerodziły się $\mathrm{w}$ otwarty konflikt, a jednocześnie stały się początkiem rozłamu w samej sekcji. Wyraźnie wykrystalizowała się opozycja wobec władz KKP PT. Tworzyły ją organizacje zakładowe z kilku mniejszych teatrów terenowych. Na jej czele stanął Region Małopolska teatralnej „Solidarności", zaś personalnie - jego przedstawiciel w Prezydium KKP PT Rajmund Jarosz oraz Szymon Pawlicki.

niezbędne jest ograniczenie dotychczasowego zakresu obowiązków Szymona Pawlickiego". Podczas zebrania Prezydium KKP PT 6 kwietnia zastrzeżenia wobec samowolnych działań Pawlickiego zgłosił przewodniczący Regionu Dolny Śląsk Zygmunt Bielawski; AKKS, KKP PT, Pismo Komisji Porozumiewawczej Instytucji Artystycznych i Środowisk Kulturalnych Województwa Gdańskiego do MKZ NSZZ „Solidarność w Gdańsku, 14 III 1981, k. 70; ibidem, Sprawozdanie z działalności KKP NSZZ „Solidarność” PT..., k. 78-79.

108 H. Słojewska, W gdańskim Oddziale ZASP po zjeździe, „Biuletyn Informacyjny ZASP-u” 1981, nr 20, s. 5.

109 AKKS, KKP PT, Sprawozdanie z działalności KKP NSZZ „Solidarność” PT..., k. 82-83.

110 „Solidarnośc” i ZASP, „Biuletyn Informacyjny ZASP-u” 1981, nr 21, s. 1.

111 AKKS, KKP PT, Sprawozdanie z działalności KKP NSZZ „Solidarność” PT..., k. 83. 
Z punktu widzenia mniejszych ośrodków sytuacja, w której rzecznikiem ich interesów stał się czołowy region teatralnej „Solidarności”, była na pewno sytuacją korzystną. Z kolei wydaje się, że w działaniach Regionu Małopolska pewną rolę odgrywać mogły względy ambicjonalne i prestiżowe. Krakowskie środowisko teatralne mimo wysokiej pozycji artystycznej na teatralnej mapie kraju, którą $\mathrm{w}$ latach 70. zawdzięczało głownie sukcesom Starego Teatru, nie miało odpowiadającego tej pozycji wpływu na życie teatralne. Działalności SPATiF-ZASP ton nadawało środowisko warszawskie. Przez całą dekadę lat 70. na jego czele stał Gustaw Holoubek, jednocześnie dyrektor warszawskiego Teatru Dramatycznego, a od 1976 r. poseł na sejm. W jego zarządzie również dominowali artyści z Warszawy ${ }^{12}$. Także ZZPKiS przewodził inny aktor-poseł Mariusz Dmochowski, będący jednocześnie dyrektorem Teatru Nowego w Warszawie. Taka sytuacja mogła być dla środowiska krakowskiego frustrująca, szczególnie jeśli weźmiemy pod uwagę sferę osobistych kontaktów z przedstawicielami władzy, o których w przytoczonej wyżej wypowiedzi mówił Gustaw Holoubek, i wypływających z nich korzyści. Cele opozycji nie były więc jednorodne. Załogi mniejszych teatrów walczyły o egzystencję, Region Małopolska o pozycję i prestiż w środowisku teatralnym.

Efektem tarć w sekcji było wzmocnienie pozycji ZASP. Władze stowarzyszenia mogły występować teraz jako główny przedstawiciel środowiska teatralnego i partner w negocjacjach $\mathrm{z}$ ministerstwem.

Na pierwszym powakacyjnym posiedzeniu Prezydium KKP PT 21 września nie pojawili się przedstawiciele trzech regionów: Małopolski, Mazowsza i Dolnego Śląska. Trudno stwierdzić, czy był to przypadek, czy efekt konfliktu narastającego $\mathrm{w}$ sekcji. W trakcie tego zebrania omawiano sprawę zjazdu teatralnej „Solidarności”. Ustalono, że odbędzie się w dwóch turach i uchwalono ordynację wyborczą ${ }^{113}$. Podjęto również decyzję, że termin zgłaszania tez programowych upływa 7 października, zaś termin zgłaszania delegatów - 15 października ${ }^{114}$. Postanowiono także uregulować relacje z ZASP ${ }^{115}$.

Przywoływane już tu kilkakrotnie wspólne posiedzenie obu organizacji, w którym nie wziął jednakże udziału przedstawiciel Regionu Małopolska ${ }^{116}$, odbyło

112 K.A. Wysiński, Związek Artystów Scen Polskich 1918-1950..., s. 59-68.

113 W październiku z zastrzeżeniami do ordynacji i żądaniem jej zmiany wystąpił Region Małopolska teatralnej „Solidarności”. W odpowiedzi przewodnicząca sekcji poinformowała, że wobec nieobecności na posiedzeniu Prezydium KKP PT przedstawiciela regionu decyzja podjęta większością głosów jest obowiązująca dla wszystkich struktur regionalnych sekcji.

114 Termin ten nie został dotrzymany. Jeszcze na początku listopada trwało zgłaszanie delegatów.

115 AKKS, KKP PT, Sprawozdanie z działalności KKP NSZZ „Solidarność” PT..., k. 83-84.

116 Halina Winiarska wyjaśniała tą nieobecność niepoinformowaniem nowego przedstawiciela Regionu Małopolska w Prezydium KKP PT, aktora Tarnowskiego Teatru im. Ludwika Solskiego Pawła Korombela. Kłóci się to z informacją udzieloną podczas zjazdu KKP PT, że o terminie posiedzenia zostali powiadomieni przedstawiciele wszystkich regionów. 
się 25 października. Region Mazowsze zaproponował powołanie komisji, która miałaby działać pomiędzy turami zjazdu teatralnej „Solidarności”, a jej zadaniem byłoby doprecyzowanie zasad współpracy. Przedstawiciele KKP PT uznali za zasadne powołanie takiego gremium podczas pierwszej tury zjazdu. Omawiano również sprawę spotkania przedstawicieli kilku teatrów terenowych w Płocku, które w uchwale wyraziło wotum nieufności zarówno wobec władz sekcji, jak i wobec ZASP ${ }^{117}$.

Rok po założycielskim zebraniu sekcji odbył się w dniach 9-10 listopada w tym samym miejscu pierwszy Zjazd KKP PT. Dotychczasowe prezydium ustąpiło, a do czasu drugiej tury zjazdu, która została zaplanowana na marzec 1982 r., władzę miało sprawować Prezydium Zjazdu, na czele którego stanął Andrzej Herder. Na zjeździe nie było przedstawiciela Komisji Krajowej NSZZ „Solidarność”, był za to pracownik DTiE MKiS Jan Siekiera. Podczas obrad dyskutowano m.in. o samorządzie teatralnym, zgłoszono wniosek dotyczący stworzenia funduszu kultury, którym zawiadywałaby specjalnie powołana w tym celu rada oraz wniosek o przeprowadzenie reorganizacji Radiokomitetu. Przedstawiciel komisji zakładowej z Teatru Dramatycznego im. Jerzego Szaniawskiego w Płocku wystąpił w obronie utrzymania istniejącej struktury teatralnej. Region Małopolska zgłosił z kolei wniosek, aby w miejsce przewodniczącego sekcji powołać ciało koordynacyjne. Pomysł ten nie uzyskał jednak akceptacji większości delegatów. Podobnie było ze zgłoszonym przez ten region projektem współpracy z ZASP. Według jego założeń wszelkie sprawy dotyczące środowiska teatralnego powinny być prowadzone przez „Solidarność”, zaś stowarzyszenie miałoby posiadać jedynie możliwość zgłaszania projektów. Zjazd podtrzymał natomiast chęć uregulowania relacji z ZASP, co znalazło wyraz w powołaniu komisji, której przewodniczącym został Zdzisław Bubella. Zarząd Główny stowarzyszenia podjął uchwałę o skontaktowaniu się z Andrzejem Herderem i wysunięciu propozycji spotkania z Prezydium Zjazdu $\mathrm{z}$ udziałem Bubelli w dniu 14 grudnia $^{118}$.

W biuletynie stowarzyszenia ukazał się sygnowany datą 16 listopada list otwarty władz ZASP do członków. Pisano w nim m.in. „Zgodnie z postanowieniami naszego Statutu i międzyorganizacyjnymi porozumieniami, raz jeszcze podkreślamy, że nie poprzemy żadnej reformy teatru, która nie znajdzie równoczesnej akceptacji ZASP-u i «Solidarności». [...] Musimy bronić czynem słusznej zasady: nic o nas bez nas, nic o teatrze bez zgody samego teatru, to jest bez zgody ZASP-u i bez zgody "Solidarności»"119. Ze względu na jego pojednawczy ton można go odczytać jako próbę nowego otwarcia w relacjach z „Solidarnością"

117 AKKS, KKP PT, Sprawozdanie z działalności KKP NSZZ „Solidarność” PT..., k. 84; IT, AZASP, sygn. 3/82, Protokół ze spotkania..., bp.

118 IT, AZASP, sygn. 3/82, Protokół z posiedzenia Prezydium ZG ZASP, 16 XI 1981, bp.

119 List otwarty Prezydium Z.G. ZASP do wszystkich członków stowarzyszenia, „Biuletyn Informacyjny ZASP-u" 1981, nr 23, s. 1-3. 
i pozyskania jej niechętnie nastawionej do stowarzyszenia części. Znalazła się w nim również zapowiedź podjęcia przez ZASP, omówionych powyżej, konkretnych działań w kwestii reformy teatralnej, czyli otwartego już wejścia w rolę związku zawodowego ${ }^{120}$.

Analizując dorobek KKP PT, trzeba stwierdzić, że był on nikły. Większość spraw i problemów, które stanęły przed teatralną „Solidarnością”, nie wyszła poza fazę wstępnych działań i konsultacji. Nie stworzono również jakiejś szerszej wizji programowej reformy życia teatralnego ani nie powołano, jak to miało miejsce $\mathrm{w}$ przypadku innych sekcji ${ }^{121}$, grupy ekspertów, która by taki program wypracowała.

Przyczyn tego stanu rzeczy było kilka. Jedną z nich był wewnętrzny konflikt, który powstał na tle stosunku do SPATiF-ZASP. Pod koniec działalności sekcji miał on już głównie charakter konfliktu personalnego.

W stosunku do stowarzyszenia "Solidarność” przejawiała tendencje monopolistyczne i starała się narzucić mu własne reguły działania. Związek, a przynajmniej jego część, w relacjach ze SPATiF-ZASP przyjął postawę oraz stosował język podobny do języka ZZPKiS z pierwszych kilkunastu lat po roku $1956^{122}$. Z kolei SPATiF-ZASP nigdy nie wyzbył się dążeń do odgrywania roli związku zawodowego. Te dwie przeciwstawne tendencje musiały doprowadzić do konfliktu.

Nienajlepsze relacje ze stowarzyszeniem ograniczały również możliwość korzystania $\mathrm{z}$ tego, co SPATiF-ZASP w przeciwieństwie do KKP PT posiadało, a mianowicie z jego zaplecza administracyjnego i prawnego. Jego brak z pewnością utrudniał przygotowywanie i koordynowanie działań podejmowanych przez sekcję.

Jeszcze inną przyczyną był krótki czas działalności teatralnej „Solidarności”, co przy złożoności problemów życia teatralnego na pewno nie było czynnikiem sprzyjającym. Do tego dochodził brak merytorycznego przygotowania członków KKP PT, bowiem duża ich część po raz pierwszy zetknęła się ze sprawami, którymi

120 Ibidem.

${ }^{121}$ Np. tego rodzaju zespół działał od jesieni 1980 r. przy Krajowej Komisji Koordynacyjnej Oświaty i Wychowania, następnie Krajowej Sekcji Oświaty i Wychowania; zob. N. Jarska, op. cit., s. $156-157$.

122 Należy w tym miejscu zasygnalizować, że stosunek „Solidarności” do SPATiF-ZASP może stanowić interesujący przyczynek do dyskusji rozpoczętej wydaną w 1984 r. książką Jadwigi Staniszkis Poland's Self-Limiting Revolution (polskie wydanie: Samoograniczająca się rewolucja, Gdańsk 2010), w której autorka stawia tezę, że ruch „Solidarności” powielał mentalność i sposób działania partii komunistycznej. Podobne stanowisko zajął Sergiusz Kowalski w pracy Krytyka solidarnościowego rozumu, Warszawa 1990. Charakter polemiczny wobec tych dwóch pozycji ma z kolei książka Pawła Rojka Semiotyka Solidarności. Analiza dyskursów PZPR i NSZZ Solidarność w 1981 roku, Kraków 2009. 
zajmowała się sekcja. Nie można również zapominać, że w przeważającej liczbie byli to ludzie czynni zawodowo, obciążeni obowiązkami w swoich teatrach, co również nie pozostawało bez wpływu na możliwości poświęcenia czasu i zaangażowania w działalność związkową.

Na to nakładał się brak wsparcia ze strony władz związku. Wydaje się jednak, że przy tak dużej liczbie istniejących sekcji branżowych ${ }^{123}$ był to problemem dotykający nie tylko teatralną „Solidarność". Do tego dochodziła ciągle nieuregulowana kwestia i tocząca się w łonie związku dyskusja na temat miejsca sekcji branżowych w strukturze „Solidarności”.

\section{Activity of branch sections of the Solidarity Trade Union in 1980-1981 on the example of the "Solidarity" National Coordinating Commission of Theatre Workers (Abstract)}

In the initial part of the paper, the history of trade unions in the Polish theatre has been outlined. Also, the situation in the theatre environment in the second half of the 1970s has been presented. In that time, the first symptoms of the conflicts, which later influenced the activity of the theatre section of "Solidarity", appeared.

Actors participated in the "Solidarity" movement since the very beginning. They took part in strikes in the coastal cities Gdańsk and Gdynia in August 1980, after which Committees of the new trade unions were established in most theatres in Poland. A need for coordination of the Committees appeared, and therefore, on the 10 November 1980, the theatre section of "Solidarity" was established. It dealt with the following issues: conditions of employment, theatre education reform, theatre's self-government, work on Saturdays, and the theatre reform. However, its actions proved to be a failure, whose main reason was the split inside the section caused by the conflict between one part of the theatre "Solidarity" with the SPATiF (Association of Polish Theatre and Film Artists) authorities. A description of the mentioned conflict forms an essential part of the present paper.

\section{Bibliografia (wybór)}

Bieniewski H., Z deszczu pod rynnę, Warszawa 2001

Biernacki L., Kazański A., NSZZ „Solidarność” Region Gdański, w: NSZZ „Solidarnośc” 1980-1989. Polska Pótnocna, t. 3, red. Ł. Kamiński, G. Waligóra, Warszawa 2010

Biernacki L., Sekcje branżowe NSZZ „Solidarność" 1980-1981, http://www.wszechnica.solidarnosc. org.pl/?page_id=247 (dostęp: 01 VI 2016)

Brzechczyn K., Program i myśl polityczna NSZZ „Solidarność”, w: NSZZ „Solidarność" 1980-1989, t. 2, red. Ł. Kamiński, G. Waligóra, Warszawa 2010

Busse A.E., Taborecik. Solidarność Zielonogórska 1980-1983, Brzezia Łąka 2011

Holzer J., „Solidarność” 1980-1981. Geneza i historia, Warszawa 1983

${ }^{123}$ W grudniu 1980 r. istniało ponad 70 sekcji, a w sierpniu 1981 już 145; L. Biernacki, Sekcje branżowe NSZZ „Solidarnośc” 1980-1981, http://www.wszechnica.solidarnosc.org.pl/?page_id=247 (dostęp: 1 VI 2016). 
Wallis A., Problemy centralizacji i decentralizacji życia kulturalnego w Polsce w latach 1945-1980, Warszawa 1981

Wysiński K.A., Związek Artystów Scen Polskich 1950-1998. Zarys dziejów, Warszawa 1998

Zwiernik P., NSZZ „Solidarność" w Zielonej Górze, w: NSZZ „Solidarność"1980-1989. Polska Zachodnia, t. 4, red. Ł. Kamiński, G. Waligóra, Warszawa 2010

Michał Rosenberg (ur. 1980), pracownik Oddziałowego Archiwum Instytutu Pamięci Narodowej w Warszawie; autor artykułów: Dziwne przypadki (?) „Dziadów” Dejmka, („Pamięć i Sprawiedliwość" 21 [2013]), Mówić pełnym głosem. Władze wobec dramatopisarzy i środowiska teatralnego na przełomie lat pięćdziesiątych i sześćdziesiątych („Pamięć i Sprawiedliwość” 24 [2014]); przygotowuje rozprawę doktorską nt. polityki władz wobec teatru w latach 1956-1981.

Kontakt: rosen3@o2.pl 